NBER WORKING PAPER SERIES

\title{
LOCAL EFFECTS OF LAND GRANT COLLEGES ON AGRICULTURAL INNOVATION AND OUTPUT
}

Michael J. Andrews

Working Paper 26235

http://www.nber.org/papers/w26235

\author{
NATIONAL BUREAU OF ECONOMIC RESEARCH \\ 1050 Massachusetts Avenue \\ Cambridge, MA 02138 \\ September 2019
}

I thank the NBER for financial support. I am very grateful to participants at the NBER conference "The Economics of Research and Innovation in Agriculture," especially to my discussant Bhaven Sampat, as well as to Jeff Furman and Nicolas Ziebarth for thoughtful comments. All errors are my own. The views expressed herein are those of the author and do not necessarily reflect the views of the National Bureau of Economic Research.

NBER working papers are circulated for discussion and comment purposes. They have not been peer-reviewed or been subject to the review by the NBER Board of Directors that accompanies official NBER publications.

(C) 2019 by Michael J. Andrews. All rights reserved. Short sections of text, not to exceed two paragraphs, may be quoted without explicit permission provided that full credit, including () notice, is given to the source. 
Local Effects of Land Grant Colleges on Agricultural Innovation and Output

Michael J. Andrews

NBER Working Paper No. 26235

September 2019

JEL No. N0,N5,O13,O3,Q1,Q16

\begin{abstract}
$\underline{\text { ABSTRACT }}$
To estimate the local effect of establishing land grant colleges, I compare locations that receive a land grant college to "runner-up" counties that were in contention to receive the land grant but did not for as-good-as-random reasons. I find that establishing a land grant college causes an increase in local invention, including in particular agricultural inventions, in college counties relative to the runner-up counties. But land grant college counties see only small and imprecisely estimated improvements in agricultural performance, measured by yield and output, relative to runner-up counties. I discuss several alternative interpretations of these findings. By comparing the establishment of land grant colleges to non-land grant colleges, I show that land grants appear to cause smaller increases in local invention, population, and agricultural output, but larger increases in agricultural yields and new crop varieties. The effect of land grant colleges on local innovations is largest, even relative to non-land grant colleges, following the passage of legislation that increases funding to agricultural research.
\end{abstract}

Michael J. Andrews

NBER

75 Lexington St.

\#3

Belmont, MA 02478

mandrews@nber.org 


\section{Introduction}

The U.S. land grant college system is frequently hailed as a major success of agricultural innovation policy (Wright, 2012). To be sure, agriculture in both the U.S. and around the world has become massively more productive over the last 150 years. Moreover, many land grant college towns are now innovative hubs (Harrington and Sauter, 2018) and frequently top lists of best places to live (Im, 2019). But to what extent are these facts caused by the presence of a land grant college, and how much is due to innate location fundamentals?

This questions is typically difficult to answer. Simply comparing places with land grant colleges to places without is unlikely to give the true causal effect of a college. Even more frustrating for researchers is that it is not clear in which direction this naive comparison is biased. On one hand, land grant colleges were likely established in up-and-coming regions, likely with access to natural amenities such as rivers to improve transportation and facilitate the diffusion of new ideas, suggesting that estimates of the effect of colleges is biased upwards. On the other hand, land grants' focus on agriculture might have induced states to locate their colleges close to farmers and far from the major cities that would allow for the exploitation of agglomeration economies, implying a downward bias. Indeed, I show below that both of these factors were important when states were deciding where to locate their land grant colleges.

To overcome these challenges, I identify cases in which the location of colleges was determined essentially at random. This randomization ensures that estimates of the local effect of land grant colleges represent the true causal effect of the college. More specifically, I use the natural experiments introduced in Andrews (2019b), identifying "runner-up" counties 
that were strongly considered to become the site of a new college but were ultimately not selected for reasons that are as good as random assignment. The first contribution of this paper is to elaborate on these selection processes, providing detailed narrative evidence that the decisions were indeed essentially random for a number of land grant colleges.

Using the runner-up counties as counterfactuals for locations that received land grant colleges, I present a number of results. First, I show that establishing a land grant college causes more local innovation. Much of the research on the local effects of colleges on innovation, including Andrews (2019b), uses patenting to proxy for innovation. ${ }^{1}$ While I show that patenting does indeed increase near land grant colleges, this measure is less likely to serve as an effective proxy for innovations in agriculture since many agricultural improvements are not patentable. ${ }^{2}$ I make some progress on this issue by using data on the location of origin of new U.S. wheat varieties introduced before 1920 (Clark, Martin, and Ball, 1922). While the data are much sparser than those for patents, even here I find that innovation increases in counties that receive land grant colleges relative to the runner-up counties. I find no evidence that land grant college counties increase their specialization in agricultural invention, measured by the share of county patents belonging to an agriculture class. While not precisely estimated, land grant colleges appear to cause an increase in county population as well, a factor that is likely to positively affect innovation but may dilute the focus on agriculture.

While land grant college counties cause sizable increases in local innovations relative to

\footnotetext{
${ }^{1}$ See also Jaffe (1989), Kantor and Whalley (2014), and Hausman (2017), for a few exemplary cases.

${ }^{2}$ While asexually reproduced plants became eligible for protection under a plant patent in 1930, and both asexually and sexually reproduced plants became utility patent-eligible in the late 1980s, none of these methods were available at the time land grant colleges were established. See Moser and Rhode (2012) and Moscona (2019) for studies on the effects of patent protection laws for plants.
} 
the runner-up counties, they have modest and imprecisely estimated effects on agricultural outcomes, including agricultural yields, total agricultural output, crop output, and livestock production. This overall finding, that land grant colleges cause sizable increases in local agricultural innovation but little increase in local agricultural output, could be interpreted either as evidence that innovations developed at land grant colleges are diffusing to the areas that will use them, or that the innovations developed at land grant colleges are irrelevant for agriculture within the state. More study is needed to distinguish between these interpretations and rule out alternative explanations.

To determine whether these observed outcomes are specific to land grant colleges, I compare my sample of land grant colleges to a sample of non-land grant colleges for which I am also able to identify runner-up locations. While measured imprecisely, land grant colleges appear to cause a smaller increase in local patenting, population, and urbanization than do other types of colleges. In terms of agricultural outcomes, the story is less clear: land grant colleges appear to cause a larger increase in local agricultural productivity relative to other types of colleges, but smaller increases in local agricultural output, and in most cases the magnitudes are small. In short, it is difficult to definitively conclude that land grant colleges play a unique role in promoting local agricultural innovation or output.

Finally, I attempt to get a sense of what drives the observed effectiveness of land grant colleges. Several pieces of legislation have been passed since the land grant college system was first established in 1862, each of which has affected land grant colleges and their role in agricultural innovation in different ways. I show that the difference in innovation between college and runner-up counties is largest following pieces of legislation that are explicitly targeted towards agricultural research, namely the 1887 Hatch Act and post-World War II 
federal funding programs, providing suggestive evidence that these laws had their intended effect. This finding is true even when comparing land grant colleges to non-land grant colleges to rule out college life-cycle effects. In sum, these historical natural experiments paint a picture in which explicit funding of agricultural research had large positive effects on the amount of measured agricultural innovation, but there is less clarity regarding how useful these innovations were or how widely they diffused.

This paper is organized as follows. Section II provides a rich description of the land grant college site selection experiments and describes the sample of colleges used in this paper. Section III presents the results and Section IV concludes.

\section{Land Grant College Site Selection Experiments}

The main difficulty with attempting to estimate the causal effect of establishing an institution of higher education, including a land grant college, is that these institutions are not located at random. For instance, colleges were often located in up-and-coming areas that were more productive and innovative than other areas in the same state, and so comparing places that get colleges to these other locations will overstate the effect of a college. At the same time, many land grant colleges were located away from productive population centers with the belief that proximity to urban areas would distract students' from their learning. On a similar note, state officials frequently wanted to locate public universities close to the geographic center of the state so that they could be equally accessible to all; these concerns often trumped desires to locate colleges in more productive areas. Indeed, many land grant colleges appear to have been located so as to be, as one university president put it, "equally 
inaccessible from all parts" of the state (Dunaway, 1946, p. 14-15). Hence, it is ex ante unclear whether college location decisions are likely to bias estimates of the effects of colleges upwards or downwards.

To overcome this challenge, I use the data and estimation strategy from Andrews (2019b). More specifically, I examine the historical record to find locations that were finalists to become the site of a new college, similar to the technique used to identify counterfactual locations for large manufacturing plants in Greenstone, Hornbeck, and Moretti (2010). I further restrict attention to cases in which the choice of the winning finalist site is as good as random assignment. I refer to the losing finalists as "runner-up" sites. Andrews (2019b) examines colleges of various types, while in this paper my primary goal is understanding the role of land grant colleges. ${ }^{3}$

Andrews (2019b) provides a detailed overview of these natural experiments, including showing that college and runner-up sites are observationally similar prior to establishing the college; showing that college and runner-up sites evolve along parallel trends prior to establishing the college; conducting numerous placebo tests; and describing qualitatively the site selection process, arguing that these decisions were fraught with randomness and unpredictability (see especially the Historical Appendix, Andrews (2019a)). I therefore take the opportunity here to describe several of these college site selection experiments in more detail than is possible in this other work, providing a deeper understanding of the kinds of historical contingencies at work while referring the reader to Andrews (2019b) for technical details.

\footnotetext{
${ }^{3}$ For the purposes of this paper, I do not consider historically black colleges and universities (HBCUs) funded under the Second Morrill Act of 1890 as land grants. Reclassifying them as land grant colleges does not qualitatively alter the results.
} 
I begin with a description of the college site selection process in North Dakota, where the state legislature literally randomly assigned the location of its land grant college, North Dakota State University (NDSU). ${ }^{4}$ In an effort to get northern towns to support the move of the Dakota Territory's capital to the south, Territorial Governor Nehemiah Ordway promised other state institutions, including the agricultural college and the state university, to towns in the north. (This push to move the capital would eventually result in the Dakotas splitting into North and South in 1889.) Representatives from the towns of Fargo, Grand Forks, Jamestown, and Bismarck all wanted one of the educational institutions, and despite furious negotiations, they could not be made to agree. Finally, in 1883, with a legislative deadline approaching, the representatives agreed in exasperation to draw lots to allocate the institutions. Fargo won the agricultural college. Seven years later, the school was formally established as the state land grant university (Geiger, 1958, p. 13-27). In the empirical analysis below, I compare Fargo to Jamestown and Bismarck, the runner-up sites, to estimate the effect of the college. ${ }^{5}$ One point worth emphasizing is that Jamestown and Bismarck looked very similar to Fargo prior to the establishment of NDSU and, as far as one can ascertain from the historical data, all had the climate, infrastructure, and temperament to successfully support a school. The point is not that the location of NDSU was random, but rather that it was random among the set of finalist locations. Thus, comparing Fargo to only the runner-up sites ensures that the comparison locations are good counterfactuals for Fargo.

\footnotetext{
${ }^{4}$ The location of the University of North Dakota was also assigned randomly at the same time and in the same manner; see Section II.A below.

${ }^{5}$ I do not consider Grand Forks as a runner-up site because it received an institution of higher education of its own. Including the few cases in which the "losing" sites receive a college does not meaningfully alter any results.
} 
Of course, literal random assignment of college sites is rather rare. More common are cases in which states set out a number of criteria that any prospective site must meet, and then painstakingly surveyed areas for their suitability. Many "wannabe" locations were eliminated at this stage. Among the remaining candidate locations, a board of trustees or site selection committee would typically meet and debate. Finally, the decision would then come to a vote. These votes were often quite contentious. I consider a candidate location to be as good as randomly assigned if, following this process in which less suitable sites are eliminated, the vote between the winner and the loser is very close. This occurred, for instance, in the cases of the University of Maine (Smith, 1979), the University of Nevada (Doten, 1924), Clemson University (Reel, 2011), and the University of Tennessee (Montgomery, Folmsbee, and Greene, 1984).

The University of California Davis provides an example of a typical site selection process. Berkeley was originally the location of California's only land grant college, but from the very beginning critics complained that Berkeley was not climatically representative of the rest of the state and so was a poor site for agricultural research. ${ }^{6}$ In 1905 , the California state legislature voted to establish a model farm operated independently of the Berkeley campus. The site selection commission was overwhelmed by more 70 offers from around the state. When narrowing down the sites, the commission set the following criteria:

The farm site should lie within the central portion of the state, in close proximity to a main railroad line, with easy access to good service; its soils should consist largely of medium loam not subject to flooding or under a level; an irrigation

\footnotetext{
${ }^{6}$ The original location of California's land grant college was selected because it was close to San Francisco but far enough away to avoid distractions. The trustees settled on Berkeley only after planned land purchases in neighboring counties fell through (Ferrier, 1930, p. 157-214).
} 
system should already be in place; and the proposed property should be situated within the vicinity of a clean and progressive town. Additionally, [the commission] thought the site ought optimally to represent the state's "typical" rainfall and general agriculture (i.e., irrigated crops) and avoid extreme heat or other insalubrious conditions. (Scheuring, 2001, p. 18)

As this quote demonstrates, representative climatic conditions and infrastructure to support farming were often explicit criteria when deciding land grant locations, providing confidence that winning and runner-up sites are likely similar in terms of their suitability for agriculture. Given the parameters of this refined search, the California commission was left with four finalist locations in Davis, Walnut Creek, Suisun, and Woodland. Although final votes among these finalists are not known, the final meeting to select among these sites dragged on for hours, highlighting just how contentious the decision was. Davis was selected only after speculators tripled the price of land at the commission's first choice. The farm was officially established in 1906 and would become an full-fledged agricultural college in 1921.

The other way in which land grant college sites were often selected was through an auction-like process. Based on the prevailing interpretation of the 1862 Morrill Act, states could use their land grant endowment to fund the operating expenses of agricultural colleges, but could not use them for purchasing land or erecting buildings. If a state wanted to create a new agricultural college from scratch, they often solicited bids from localities in the state. I consider the college site to be as-good-as-randomly assigned if candidates' bids are known and the winning bid is very similar to that of losing candidates. These close bidding processes are typically also followed by a contentious vote among a site selection committee. 
These auction-type processes occur for schools such as the University of Arkansas (Reynolds and Thomas, 1910), the University of Illinois at Urbana-Champaign (Turner (1932), Solberg (1968)), Iowa State University (Ross, 1958), the Missouri University of Science \& Technology (Roberts, 1946), and the University of Missouri (Rees and Walsworth (1989), Burnes (2014)).

In many cases, the decision of where to locate a college was not only contentious among a site selection committee, but among the residents of the state as well. The University of Florida provides such an example. In 1905, the state of Florida had eight small institutions of higher education scattered across the state. In an effort to consolidate, the legislature passed the Buckman Act, which closed the existing institutions, re-evaluated the best locations, and then re-established the college at a potentially new site. Gainesville and Lake City quickly emerged as the clear frontrunners to become the new site of the college. Lake City had the added distinction of being the site of the previous Florida Agricultural College. Both Gainesville and Lake City submitted bids of similar amounts, and when it came time for the Board of Control of the university system to vote on the matter, Gainesville won over Lake City, six to four, following a contentious debate. But as acrimonious as the vote was, it paled in comparison to the views of the citizens of Lake City: as materials from the former agricultural college were being packed to move to their new home in Gainesville, they were done so under an armed guard for fear of rioting (Proctor and Langley, 1986, 18-26).

In still other cases, unusual "fluky" events proved decisive in determining the location of land grant colleges. The establishment of Cornell University (New York's land grant college and the only private land grant institution) provides such an example. What would become Cornell University was originally intended to be located at the People's College in Havana, New York, but the state senator sponsoring the bill suffered an ill-timed stroke, delaying the 
decision. Later, the legislature was strongly considering placing the college in Ovid when a well-known advocate for the compassionate treatment of the insane died mid-speech before the state assembly in Albany. State senators Andrew White and Ezra Cornell were able to use the death to convince the legislature that Ovid should receive an insane asylum instead of a college. Satisfied with the arrangement, Ovid's representatives then decided to support whatever location White and Cornell decided to endorse, creating a dominant legislative coalition (Bishop (1962), Kammen (2003)). Even then, the decision was not settled: White and Cornell each wanted to place the college in their hometowns, with White being from Syracuse and Cornell from Ithaca. But Cornell adamantly refused to allow the college to be located in Syracuse, because as a young man he had been "robbed [there] not once but twice" (Kammen, 2003, p. 2003); White and Cornell settled on Ithaca instead.

Other colleges provide further examples of serendipity determining a school's location. Louisiana State University moved to Baton Rouge after its prior location burned down, and only a few sites in the state had the infrastructure to take on the school on short notice (Fleming, 1936). There are even accounts (possibly apocryphal) that the location of Texas Agricultural and Mechanical University was decided by a poker game (Dethloff, 1975, p. 18)!

Even acts of God intervened to determine college location. In 1885, Arizona's famous (or infamous) "Thieving Thirteenth" legislature met to divvy up the territory's state institutions. The citizens of Tucson had their hearts set on obtaining the state insane asylum when they set off for the legislative assembly in Prescott. But flooding on the Salt River delayed the Tucson delegates, and when they arrived in Prescott the insane asylum had already been spoken for. The people of Tucson were stuck with the state's land grant college, which became the University of Arizona (Martin (1960, p. 21-25), Wagoner (1970, p. 194-222), 
Cline (1983, p. 2-4)).

As these examples illustrate, the narrative historical record contains rich details about both the locations that received land grant colleges and those that were strongly considered but ultimately did not. Some of these details suggest variation that may be useful for additional analysis. For example, in the case of North Dakota State and the University of Arizona, the "losing towns" that did not receive the land grant college received another type of institution instead. Likewise, in the case of Cornell University, Ovid received an insane asylum in lieu of the land grant college. Syracuse, another runner-up for Cornell University, did not receive any other institution at the time Cornell was established, but did receive a university of its own within a few decades. In this paper, I abstract from these issues, but I discuss them in some detail in Andrews (2019b). Analysis of other types of heterogeneity, such as exploring more finely differences across types of institutions, geography, or other local conditions, may be of interest for future work. All of this is possible using the details available in the narrative record.

\section{II.A Non-Land Grant Colleges}

Similar strategies can be used to determine runner-up locations for non-land grant colleges as well. As mentioned above, North Dakota drew lots to determine the location of its flagship public university, the University of North Dakota, as well as its land grant college. In the case of the Georgia Institute of Technology, 24 rounds of balloting were required before Atlanta was selected over Macon (McMath Jr., Bayor, Brittain, Foster, Giebelhaus, and Reed, 1985, p. 24-32). For Southern Arkansas University, eight rounds of balloting were 
required (Willis, 2009, p. 21-43), and the University of Mississippi took seven (Sansing, 1999, p. 1-24). ${ }^{7}$ Auction-like processes and other "fluky" events are likewise common for the non-land grant colleges.

In this paper, I use non-land grant colleges as a set of "control institutions" to gain a sense of whether or not the effects I observe from establishing land grant colleges are caused by policies specifically related to land grants or whether they are common to all institutions of higher education. Appendix A lists more details about the sample of non-land grant colleges used in this paper.

\section{II.B The Sample of Colleges}

In total, there are 29 cases in which the site selection decision for a land grant college was as-good-as random, representing $55 \%$ of the 53 non-HBCU U.S. land grant institutions. As in Andrews (2019b), all results in this paper are robust to dropping individual colleges or types of site selection decisions. Table 1 list each of these 29 colleges, the winning county of each, the runner-up counties, and the year in which the college is established.

Table 2 presents summary statistics of the land grant college site selection experiments. The median land grant college had one runner-up county, with the mean having about 1.5 runner-up counties. The median runner-up site is about $110 \mathrm{~km}$ from the college site, although there is considerable heterogeneity, with the mean runner-up $150 \mathrm{~km}$ away, the farthest runner-up $550 \mathrm{~km}$ away, and the closest runner-up being only $30 \mathrm{~km}$ away.

Throughout this paper, I define the year in which a college is established to be the year

\footnotetext{
${ }^{7}$ Southern Arkansas University actually began as an agricultural school, although it was not a land grant college. The results in this paper are insensitive to dropping schools like Southern Arkansas or reclassifying them as "land grants."
} 
in which the college site is selected as described in the college site selection experiments above. In some cases, this date is not the same as the date in which an institution was formally founded, nor need it coincide with the date at which the college opened its doors. Results are unchanged when using the first year when students attended or the first year students graduated as the establishment year. In Section III.B, I investigate the importance of other dates in a college's life, such as the year colleges began receiving reliable federal research funding. Most of the sample colleges selected their sites and opened their doors in the first decade and a half after the Morrill Land Grant Act was passed. Two schools were established before the act and obtained land grant status later. Western states typically established their land grant colleges around the same time they obtained statehood, with several states doing so in the 1880s and 1890s. Southern states could not take advantage of the Morrill Act while in rebellion against the U.S. government during the Civil War, so all southern schools in the sample established their colleges in 1869 or later. There is thus substantial temporal variation in the establishment of land grant colleges.

\section{Results}

Figure 1 plots four different outcome variables for the land grant and runner-up counties over time. Year 0 is normalized to be the year in which each land grant college is established. In Panel (a), I plot logged patenting, in Panel (b) logged county population, Panel (c) logged agricultural yield (that is, $\left.\log \left(\frac{\text { ValueAgr.Output }}{\text { FarmAcres }}\right)\right)$, and Panel (d) the logged value of all agricultural output. Throughout, all U.S. patenting data come from the dataset assembled in Berkes (2018); population data come from the National Historical Geographic Information 
System (Manson, Schroeder, Riper, and Ruggles, 2018); and all agricultural data comes from agricultural censuses, cleaned and compiled by Haines, Fishback, and Rhode (2018). For the population and agricultural data that comes from federal census data, I linearly interpolate values for all between-census years; unless otherwise noted, results are not sensitive to alternative interpolation approaches or to only using data from census years.

These four pictures tell the main story of this chapter: counties that receive a land grant college see a measurable increase in local invention, especially after about five decades. There is weak and noisy evidence that land grant colleges also cause increases in population, a major driver of local invention for the larger sample of colleges considered in Andrews (2019b). But the counties that receive land grant colleges see no clear increase in agricultural productivity or output relative to the runners-up; while the agricultural measures fluctuate over time, these fluctuations are typically common to both the college and runner-up counties.

Table 3 confirms these results in a regression framework. I estimate the simple differencesin-differences model:

$$
\begin{aligned}
Y_{i t}= & \beta_{1} \text { LandGrantCount }_{i} \times \text { PostLandGrant } \\
i t & +\beta_{2} \text { Post LandGrant }_{i t} \\
& + \text { County }_{i}+\text { Year }_{t}+\epsilon_{i t} .
\end{aligned}
$$

LandGrantCounty $_{i}$ is an indicator variable equal to one for the counties that receive land grant colleges. PostLandGrant $i$ is an indicator variable equal to one in years $t$ after the establishment of the college for which county $i$ was either the winner or runner-up. County is a county fixed effect, Year ${ }_{t}$ is a year effect, and $\epsilon_{i t}$ an idiosyncratic error term. The estimation sample is made up of the college and runner-up counties for all years for which 
data is available; not all variables are available for all years. In all regressions that follow, I cluster standard errors at the county level.

I estimate effects of establishing a land grant college for a larger battery of outcome variables than I present in Figure 1. Panel (a) of Table 3 shows results for innovation and population outcomes. Column 1 confirms the results from Panel (a) of Figure 1: establishing a land grant college causes about $54 \log$ points more patents per year relative to the runner-up counties. Column 2 specifically examines patents classified as agricultural according to the NBER patent classification system (Hall, Jaffe, and Trajtenberg, 2001). While the estimated coefficient is positive, it is imprecisely estimated and much smaller in magnitude than overall patenting, at a roughly nine log point increase in agricultural patents per year. Column 3 shows that there is no significant change in the fraction of agricultural patents in land grant college counties after establishing a new college. ${ }^{8}$

One challenge with measuring agricultural innovation is that many important breakthroughs, particularly the development of new and improved crop varieties, are not patented (Olmstead and Rhode, 2008). ${ }^{9}$ To provide some insight into the location of non-patented agricultural invention, I consult a USDA technical report (Clark et al., 1922) that attempts to classify every variety of wheat grown in the United States as of 1920. Crucially, and exceedingly rare among agricultural studies, the authors also provide histories of each wheat variety, including how, when, and where each variety was developed and/or introduced to the

\footnotetext{
${ }^{8}$ This variable is constructed as the number of agricultural patents divided by the number of patents with a known patent class (Marco, Carley, Jackson, and Myers, 2015). Patent class information is still missing for some patents, particularly older patents. This measure is undefined when the class is unknown for all patents in a county in a given year.

${ }^{9}$ This is not to say that patent data is irrelevant to an understanding of agricultural innovation, only that patent data alone paints an incomplete picture. Improvements in farm implements and mechanized equipment, often highlighted as vital contributors to American agricultural development (Cochrane (1979), Hayami and Ruttan (1985)) were patentable.
} 
United States. This allows me to investigate the extent to which land grant colleges directly contributed to innovation in the wheat sector. ${ }^{10}$ Because individual counties are extremely unlikely to develop more than one variety in a given year, in Column 4 I present estimates from a regression in which the outcome variable is an indicator that is equal to one if a county develops a new variety in that year and zero otherwise. ${ }^{11}$ Establishing a land grant college causes a small but statistically significant increase in the likelihood of introducing a new crop variety, on the order of $2 \%$.

Consistent with Panel (b) of Figure 1, Column 5 shows that establishing a land grant college causes a positive but statistically insignificant increase in total population of about ten $\log$ points. The fraction of the county population living in urban areas, shown in Column 6 , is also positive but statistically insignificant, and is close to zero in magnitude.

In Panel (b) of Table 3, I show results for various agricultural outcomes. In Column 1, I show that establishing a new college has no statistically significant effect on agricultural yields, although the coefficient is positive and non-trivial in magnitude, equal to a roughly ten log point increase in agricultural productivity relative to the runner-up counties. One issue with yields as an outcome variable is that it is defined as the value of agricultural output divided by agricultural land, and establishing a new college may affect both the numerator and the denominator. In particular, a successful land grant college may induce more marginal land to come into agricultural production, decreasing yields while increasing output. In columns 2-4, I estimate the effect of establishing a land grant college on several

\footnotetext{
${ }^{10}$ In ongoing work, I attempt to transcribe more recent USDA reports that contain histories of crop varieties developed in later years, as well as to gather data on yields or other measures of quality for the different varieties. I thank Paul Heisey for pointing out the existence of these later reports and discussing their potential usefulness for research on the geography of invention.

${ }^{11}$ Because the USDA report (Clark et al., 1922) was based on data collected in 1919 and 1920, the outcome variable is unavailable for years after 1920.
} 
output measures: the total value of agricultural output, the value of crop output, and the value of livestock produced. In all cases, establishing a land grant college has statistically insignificant effects, although in the effect is positive and sizable in magnitude for agricultural output and crop output. ${ }^{12}$ This suggests that the land grant counties are increasing the amount of agricultural land relative to the runner-up counties, consistent with untabulated results on the amount of improved farm acreage.

I repeat this exercise in Appendix B with a larger, although likely less randomly located, sample of colleges and find similar effects of establishing a college on innovation outcomes but smaller or even negative effects on agricultural outcomes. The sensitivity of the agricultural productivity and output results to the exact sample of data used highlights how noisy the agricultural outcomes are across time and location, and the agricultural results should be treated with caution.

Even setting aside data concerns, the large positive coefficients for local innovation outcomes and small-in-magnitude and statistically insignificant coefficients for agricultural outcomes lend themselves to several possible interpretations. One interpretation is that the agricultural innovations documented in Panel (a) of Table 3 successfully diffuse throughout the land grant college's state, so the county from which these innovations originated saw little benefit from them relative to the otherwise similar runner-up counties. Alternatively, the results could be interpreted as evidence that the innovations developed in land grant college counties are irrelevant to agricultural production in the state, or that the agricultural outcome measures are mismeasuring true agricultural productivity. Much more work

\footnotetext{
${ }^{12}$ The agricultural results here present one case in which interpolation meaningfully alters point estimates. When using only data from agricultural census years, the coefficients for agricultural productivity, agricultural output, and crop output are all smaller in magnitude, and the coefficient on agricultural output becomes negative. These results are available upon request.
} 
is needed to conclusively determine which of these interpretations is most correct.

\section{III.A Comparing Land Grant Colleges to Other Types of Colleges}

Is there something "special" about the land grant college program, or would the observed positive effects on innovation be observed anytime an institution of higher education is established? To answer this question, I use data from all college site selection experiments, not just the land grants.

Figure 2 plots the difference between college and runner-up counties separately for land grant and non-land grant colleges for the same four outcome variables as in Figure 1. Both types of colleges had small and largely constant differences prior to the colleges being established. ${ }^{13}$ Both types of colleges exhibit an increase in patenting and population after establishment, although at different rates. In particular, while the non-land grant college counties see almost immediate increases in local population relative to their runner-up counties, the land grant college counties see large increases in population only after about seven decades. The pictures for agricultural productivity and output are less clear, with particularly large fluctuations for land grant colleges but no obvious trend.

I next test the difference between the types of colleges more formally in a triple differences

\footnotetext{
${ }^{13}$ In all cases, I fail to reject the null hypothesis of parallel pre-trends for both the land grant and non-land grant colleges; results are available upon request. The plotted figures can be misleading in the earliest years since data is not available for all colleges three decades before the college establishment date.
} 
framework. I estimate

$$
\begin{aligned}
Y_{i t}= & \beta_{1} \text { CollegeCount }_{i} \times \text { PostCollege }_{i t} \times \text { LandGrant }_{i} \\
& +\beta_{2} \text { CollegeCounty }_{i} \times \text { PostCollege }_{i t} \\
& +\beta_{3} \text { LandGrant }_{i} \times \text { PostCollege }_{i t} \\
& +\beta_{4} \text { PostCollege }_{i t}+\text { County }_{i}+\text { Year }_{t}+\epsilon_{i t}
\end{aligned}
$$

where CollegeCounty $y_{i}$ is a dummy equal to one if county $i$ ever receives a college of any type, PostCollege $i t$ is a dummy equal to one in years $t$ after the establishment of the college for which county $i$ was either the winner or runner-up, and LandGrant ${ }_{i}$ is a dummy equal to one if $i$ was either the winner or runner-up for a land grant college.

I present results in Table 4, for the same outcome variables as measured in Table $3{ }^{14}$ The variable of interest, CollegeCount $y_{i} \times$ PostCollege $_{i t} \times$ LandGrant $_{i}$, is rarely statistically significant, which is not surprising given the relatively small number of college experiments. Nevertheless, the coefficients suggest an interesting pattern. Land grant colleges appear to cause about nine log points less of an increases in local patenting than do the non-land grant colleges. Land grant colleges also appear to cause less of an increase in agricultural patenting, although the coefficient is close to zero in magnitude. But when focusing on non-patentbased agricultural innovations, land grant colleges do have a larger effect than the non-land grants: land grant colleges cause a $2 \%$ increase in the likelihood of introducing new wheat varieties relative to the non-land grant colleges, an effect statistically significant at the $10 \%$

\footnotetext{
${ }^{14}$ Results comparing land grant to non-land grant colleges are similar when restricting the sample of nonland grants to include only public colleges (typically flagship state universities that are not also land grant colleges, such as the University of North Dakota), although the smaller sample of colleges results in less precise estimates; these results are available upon request.
} 
level. Land grant colleges also cause cause less population growth and urbanization than do the non-land grant colleges. Agricultural productivity appears to increase more in counties that receive a land grant college than in counties that receive other types of colleges, but if anything land grant colleges cause worse outcomes in terms of total agricultural output, crop output, and livestock.

The coefficient on CollegeCounty $\times$ PostCollege $i$ measures the effect of establishing non-land grant colleges and shows that these other types of institutions also generate sizable increases in local patenting and agricultural patenting, as well as creating positive but statistically insignificant and small in magnitude increases in agricultural output. Unlike the land grant colleges, the non-land grant colleges create large increases in local population and statistically significant increases in urbanization. The coefficient on LandGrant $_{i} \times$ PostCollege $_{i t}$ measures how the land grant runner-up counties perform after establishing a land grant college relative to the non-land grant runners-up after establishing a non-land grant college, and is thus a plausible measure of spillovers from land grants. The coefficient is negative for agricultural productivity, agricultural output, and crop output, although it is positive for all measures of innovation. This calls into question whether the land grant colleges were more effective at generating innovations that diffused throughout their states than were other types of colleges. Conclusions about spillovers and diffusion should be made with caution, however, since the non-land grant runner-up counties may be exposed to innovations from a nearby land grant college, and vice versa. A full exploration of these issues is beyond the scope of this paper. 


\section{III.B What Pieces of Land Grant Legislation Were Most Effec-}

\section{tive?}

The current land grant college system is the result of several pieces of legislation, from the 1862 Morrill Act to the most recent farm bill, each of which affected the local innovation ecosystem in different ways. To speak of "the effect" of land grant colleges is therefore to obscure many distinctions that may be important for policymakers. As a first pass at understanding which pieces of legislation had the largest local effect, I repeat the basic differencesin-differences analysis from above, but define multiple "post-period" dummy variables that are equal to one during time periods that denote given legislative epochs. I examine the difference between land grant college counties and runner-up counties following the initial establishment of land grant colleges under the Morrill Act of 1862, the establishment of agricultural experiment stations following the Hatch Act of 1887, and the post-World War II era in which the federal government became much more directly involved in research funding, exemplified by the 1946 Research and Marketing Act. ${ }^{15}$ Each of these dates marks a commonly-recognized turning point in the funding of higher education, particularly in relation to agricultural research. Numerous studies highlight the pioneering role of the 1862 Morrill Act in establishing institutions dedicated to agricultural education and research, including several full-length histories (Edmond (1978), Cross (1999, p. 77-94), Geiger and

\footnotetext{
${ }^{15}$ Many other important pieces of legislation could be studied as well, such as the Second Morrill Act of 1890 that established additional land grant colleges, especially for African Americans; the 1906 Adams Act that provided additional federal funding for scientific research; the 1925 Purnell Act that provided federal funding for applied research to aid the local agricultural sector; or the 1935 Bankhead-Jones Act, which introduced formula funding and federal and state matching grants for basic agricultural research. Alston and Pardey (1996) provide a useful summary of major legislation related to agricultural research. In additional untabulated analysis, I consider the effects of these other pieces of legislation as well. Unfortunately, many of the acts occurred within a decade or two of one another, making it extremely difficult to determine the effects of particular laws. I therefore focus on what I consider the most important changes in legislation, with the caveat that more additional research is needed to conclusively determine the effects of each policy.
} 
Sorber (2013), Sorber (2018)). A sizable literature also examines the effects of the 1887 Hatch Act, which established state agricultural experiment stations and provided federal funding to conduct research at those stations, marking the beginning of direct federal funding of agricultural research activities (Kerr (1987), Ferleger (1990), Hillison (1996), Kantor and Whalley (2019)). The 1946 Research and Marketing Act, which dramatically increased federal spending on state agricultural experiment stations and reorganized the administration of federal agricultural research support, has been the least examined by historians of agriculture or education, although it has not been completely ignored (Bowers (1946), Alston and Pardey (1996)). More broadly, the 1946 Act exemplifies the federal government's changing approach in the postwar world, with the end of World War II widely recognized as a watershed moment in the federal government's support for university research (Geiger (1993), Rosenberg and Nelson (1994), Mowery and Rosenberg (1998), Mowery and Sampat $(2001))$.

I estimate the following model:

$$
\begin{aligned}
& Y_{i t}=\beta_{1} \text { LandGrantCounty }_{i} \times \text { PostMorrillAct }_{i t}+\beta_{2} \text { LandGrantCount }_{i} \times \text { PostHatchAct }_{i t}
\end{aligned}
$$

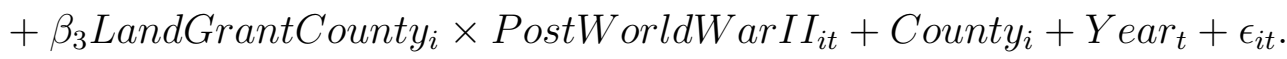

where PostMorrilAct equals one for $1862 \leq t<1887$, PostHatchAct equals one for $1887 \leq$ $t<1946$, and PostWorldWarII equals one for $1946 \leq t .{ }^{16}$ I focus on the first cohort of land grant colleges, established between 1862 and 1870, to see how a constant set of colleges changes over the lifecycle.

\footnotetext{
${ }^{16}$ Results are similar when replacing the year fixed effects with the much coarser time period dummies for PostMorrilAct, PostHatchAct, and PostWorldWarII.
} 
I present results in Table 5. When splitting up the patenting results into four time periods (the pre-period before 1862 Morrill Act, which is the base time, and the time periods corresponding to each of the three interaction terms), individual coefficients are typically not statistically significant. It appears that the college counties only begin to see larger levels of patenting relative to the runners-up after the passage of the Hatch Act, with an even larger increase observed after World War II. Agricultural patenting, however, exhibits a different pattern, with the increase in the level of agricultural patents increasing in college counties relative to runners-up immediately following the passage of the Morrill Act while falling to almost zero following the Hatch Act and finally rebounding after World War II. The fraction of agricultural patents appears to increase in land grant college counties relative to the runners-up after the Morrill and Hatch Acts, but decreases after World War II, although the post-World War II magnitude is small. ${ }^{17}$ Population and urbanization exhibit increases in college counties relative to the runners-up that are large in magnitude following World War II: total population increases by a statistically significant $54 \log$ points, with urbanization increases by nine log points. Total population shows a sizable eleven log point increase following the Hatch Act as well. For agricultural productivity, agricultural output, and crop output, the land grant college counties see a decrease relative to the runner-up counties following the Morrill and Hatch Acts before seeing increases after World War II, although most of these coefficients are fairly small in magnitude, with magnitudes between two and thirteen $\log$ points. Livestock products actually exhibit the largest increase in college counties relative to the runners-up in the years following the Morrill Act, making it difficult to tell a

\footnotetext{
${ }^{17}$ Because the data on the introduction of new wheat varieties is from a 1922 report (Clark et al., 1922), no post-World War II observations are available and so I do not examine that outcome variable in Table 5.
} 
consistent story about the role of each piece of legislation on local agricultural outcomes.

While suggestive, interpreting the results in Table 5 is difficult. New colleges began as very small institutions that then grew over time, raising the possibility that larger differences between the college and runner-up counties after 1887 or 1946 are driven by the "natural" growth of these colleges rather than by specific policies. To attempt to account for this, I compare the effect of the 1862-1870 land grant colleges to the effect of other types of colleges that were established between 1860 and 1870.

Figure 4 shows the difference in patenting between college and runner-up counties for this cohort of colleges, where calendar years are plotted on the $x$-axis and the passage of the Morrill, Hatch, and Research and Marketing Acts are indicated. The land grant college counties see sizable increases in the number of patents relative to the runner-up counties beginning in the early 1900s, while a similar takeoff for the non-land grant college counties 
does not begin until about $1960 .^{18}$ To formalize these findings, I estimate

$$
\begin{aligned}
Y_{i t}= & \beta_{1} \text { CollegeCounty }_{i} \times \text { PostMorrillAct }_{i t} \times \text { LandGrant }_{i} \\
& +\beta_{2} \text { CollegeCount }_{i} \times \text { PostHatchAct }_{i t} \times \text { LandGrant }_{i} \\
& +\beta_{3} \text { CollegeCounty }_{i} \times \text { PostWorldWarI }_{i t} \times \text { LandGrant }_{i} \\
& +\beta_{4} \text { CollegeCounty }_{i} \times \text { PostMorrillAct }_{i t}+\beta_{5} \text { CollegeCount }_{i} \times \text { PostHatchAct }_{i t} \\
& +\beta_{6} \text { CollegeCounty }_{i} \times \text { PostWorldWarII }_{i t}+\beta_{7} \text { LandGrant }_{i} \times \text { PostMorrillAct }_{i t} \\
& +\beta_{8} \text { LandGrant }_{i} \times \text { PostHatchAct }_{i t}+\beta_{9} \text { LandGrant }_{i} \times \text { PostWorldWarI }_{i t} \\
& + \text { County }_{i}+\text { Year }_{t}+\epsilon_{i t} .
\end{aligned}
$$

The triple interaction terms $\beta_{1}-\beta_{3}$ show the effect of establishing a land grant college relative to the effect of establishing other types of colleges in each time period. The interaction terms $\beta_{4}-\beta_{6}$ show the average effect of establishing non-land grant colleges in each time period, while the interaction terms $\beta_{7}-\beta_{9}$ show the difference between all counties under consideration to receive a land grant college and all counties under consideration for other types of colleges in each time period. The assumption needed to identify the triple interactions terms of interest is that, without the research-related legislation, land grant and non-land grant colleges of the same age would have similar effects on the local economy at every point in time.

Results are presented in Table 6. For readability, I only present coefficient estimates for the triple interactions terms, $\beta_{1}-\beta_{3}$; full results are available upon request. All coefficients of interest are, again not surprisingly, not statistically significant, but many are large in

\footnotetext{
${ }^{18}$ The differences in the relative dynamics of patenting between Figures 4 and 2 is due to the fact that the figures are plotting patenting for a different sample of colleges, with Figure 4 containing only the schools established between 1860 and 1870 .
} 
magnitude. After the Morrill Act, land grant colleges appear to cause roughly 15 log points less of an increase in local patenting than the non-land grant colleges. This reverses after the Hatch Act, with land grant colleges increases local patenting relative to their runner-up counties by $46 \log$ points more than the non-land grant colleges after the Hatch Act and 37 log points more after World War II. Land grant colleges cause larger increases in the level of agricultural patenting than do the non-land grant patents for all three periods, although in all periods the land grant colleges cause a decline in the share of agricultural patents relative to the non-land grant colleges, with the largest decline in the share of seven log points occurring after the passage of the Hatch Act.

The land grant colleges cause less of an increase in population after the Morrill and Hatch Acts than do the non-land grant colleges, although following World War II the land grant colleges have cause a roughly $25 \log$ points larger increase in population than do the non-land grant colleges. In all three periods, the land grant colleges appear to cause a larger increase in urbanization (or, at least, less of a decrease), although the magnitudes are very small until after World War II. Land grant colleges cause a larger increase in agricultural productivity only after World War II, although they cause an increase in agricultural output and crop output following the Hatch Act as well, and an increase in the value of livestock products sold in all three periods. If anything, land grant colleges cause a decline in agricultural productivity, agricultural output, and crop output relative to the non-land grant colleges in the initial decades following the passage of the Morrill Act. I stress again that these differences are all statistically insignificant and should be interpreted with caution.

Facilitating comparisons of different types of institutions over distinct epochs of federal involvement in agricultural research opens the door to many interesting lines of study. 
Changes that occur in the postwar period are particularly interesting because, while legislation such as the 1946 Research and Marketing Act specifically targeted agricultural research that was largely conducted at land grant colleges, postwar federal involvement in science and research occurred in nearly all sectors, not merely agriculture. ${ }^{19}$ The fact that land grant colleges had a long-established history of supporting applied research may have made land grant colleges a particularly attractive destination of federal funding in the postwar era; I leave a deeper exploration of this issue to future work.

\section{Conclusion}

In this paper, I provide detailed descriptions of the processes through which states decided where to locate their land grant colleges. Serendipity frequently played a role in determining college location, and I exploit this fact to identify runner-up sites that would have received land grant colleges but for as-good-as-random reasons.

Using these runner-up sites as counterfactuals for locations that receive a land grant college, I show that establishing a land grant college causes more local agricultural innovation, measured both by patents and new crop varieties. While land grant colleges cause an increase in innovation, they cause small and imprecisely estimated improvements in agricultural performance relative to the runner-up counties. These results lend themselves to several interpretations. One interpretation is that innovations developed at land grant colleges diffuse effectively, but it could also be the case that land grant college innovations

\footnotetext{
${ }^{19}$ One may worry that only a few federal institutions dominated postwar federal funding, and that these institutions are missing from my sample. O'Mara (2005), for example, documents how skewed federal funding was across institutions. While MIT and Stanford are not in my sample, Georgia Tech (which would increase its share of federal funding in the 1960s and 1970s) is included as a non-land grant college.
} 
have limited relevance to farmers working within the same state. Additional research is needed to determine how the diffusion process for land grant innovations operates. Kantor and Whalley (2019) provide a promising first step in this direction, focusing on the role of geographic proximity and communications technologies in explaining the diffusion from land grant colleges, but much work remains to be done.

More work is also needed to understand exactly what types of policies led to the success of the land grant program, and which of these policies can be replicated in other contexts or with other types of institutions. In this paper I present suggestive evidence that the Hatch Act and post-World War II federal funding, both of which provided direct federal support for agricultural research, were particularly effective in promoting local invention. Limited variation in the implementation of similar large scale policies makes these types of questions difficult to answer today. While the historical evidence presented in this paper is not conclusive, my hope is that the data and methodology presented here will prove to be of continuing utility in addressing important questions for agricultural innovation policy.

\section{References}

Alston, J. M. and P. G. Pardey (1996). Making science pay: the economics of agricultural RED policy. Washington, DC: American Enterprise Institute Press.

Andrews, M. J. (2019a). Historical appendix: How do institutions of higher education affect local invention? Evidence from the establishment of U.S. colleges. Unpublished, NBER.

Andrews, M. J. (2019b). How do institutions of higher education affect local invention? Evidence from the establishment of U.S. colleges. Unpublished, NBER.

Berkes, E. (2018). Comprehensive universe of U.S. patents (CUSP): data and facts. Unpublished, Ohio State University.

Bishop, M. (1962). A history of Cornell. Ithaca, NY: Cornell University Press. Drawings by Alison Mason Kingsbury.

Bowers, D. E. (1946, January). The Research and Marketing Act of 1946 and its effects on agricultural marketing research. Agricultural History 56(1), 249-263.

Burnes, B. (2014). Missou175: the remarkable story of Missouri's flagship university from 1839 to 2014. Kansas City, MO: Rockhill Books. 
Clark, J. A., J. H. Martin, and C. R. Ball (1922). Classification of American wheat varieties. Bulletin 1074, Washington.

Cline, P. (1983). Mountain campus: the story of Northern Arizona University. Flagstaff, AZ: Northland Press.

Cochrane, W. W. (1979). The development of American agriculture: a historical analysis. Minneapolis: Univeristy of Minnesota Press.

Cross, C. F. (1999). Justin Smith Morrill: father of the land-grant colleges. East Lansing, MI: Michigan State University Press.

Dethloff, H. C. (1975). A centennial history of Texas A\&M University, 1876-1976, Vol. I. College Station, TX: Texas A\&M University Press.

Doten, S. B. (1924). An illustrated history of the University of Nevada. The University of Nevada.

Dunaway, W. F. (1946). History of the Pennsylvania State College. Lancaster, PA: Lancaster Press, Inc.

Edmond, J. B. (1978). Magnificent charter: the origin and role of the Morrill land-grant colleges and universities. New York: Exposition Press.

Ferleger, L. (1990, Spring). Uplifting American agriculture: experiment station scientists and the Office of Experiment Stations in the early years after the Hatch Act. Agricultural History $64(2), 5-23$.

Ferrier, W. W. (1930). Origin and development of the University of California. Berkeley, CA: The Sather Gate Book Shop.

Fleming, W. L. (1936). Louisiana State University: 1860-1896. Baton Rouge, LA: Louisiana State University Press.

Geiger, L. G. (1958). University of the northern plains: a history of the University of North Dakota, 1883-1958. Grand Forks, ND: The University of North Dakota Press.

Geiger, R. L. (1993). Research and relevant knowledge: American research universities since World War II. Oxford: Oxford University Press.

Geiger, R. L. and N. M. Sorber (Eds.) (2013). The land-grant colleges and the reshaping of American higher education. New Brunswick, NJ: Transaction Publishers.

Greenstone, M., R. Hornbeck, and E. Moretti (2010, June). Identifying agglomeration spillovers: evidence from winners and losers of large plant openings. Journal of Political Economy 118(3), 536-598.

Haines, M., P. Fishback, and P. Rhode (2018). United States agricultural data, 1840-2012 (ICPSR 35206). https://www.icpsr.umich.edu/icpsrweb/ICPSR/studies/35206/ publications, accessed May 12, 2019.

Hall, B. H., A. B. Jaffe, and M. Trajtenberg (2001). The NBER patent citation data file: lessons, insights and methodological tools. NBER Working Paper.

Harrington, J. and M. B. Sauter (2018, November 14). The 25 most innovative cities in US share affinity for technology. USA Today. https://www. usatoday.com/story/money/ 2018/11/14/top-cities-entrepreneurs-tech-25-most-innovative-places-us/ $38330651 /$.

Hausman, N. (2017). University innovation and local economic growth. Unpublished, Hebrew University.

Hayami, Y. and V. W. Ruttan (1985). Agricultural development: an international perspective. Baltimore: Johns Hopkins University Press. 
Hillison, J. (1996). The origins of agriscience: or where did all that scientific agriculture come from? Journal of Agricultural Education 37(4), 8-13.

Im, J. (2019, April 29). These are the 10 best places to live in the US in 2019. $C N B C$. https://www.cnbc.com/2019/04/15/us-news-world-report-best-places -to-live-in-the-us-in-2019.html.

Jaffe, A. B. (1989, Dec). Real effects of academic research. American Economic Review 79(5), $957-970$.

Kammen, C. (2003). Cornell: glorious to view. Ithaca, NY: Cornell University Library.

Kantor, S. and A. Whalley (2014, March). Knowledge spillovers from research universities: evidence from endowment value shocks. Review of Economics and Statistics 96(1), $171-188$.

Kantor, S. and A. Whalley (2019, April). Research proximity and productivity: long-term evidence from agriculture. Journal of Political Economy 127(2), 819-854.

Kerr, N. A. (1987). The legacy: a centennial history of the state agricultural experiment stations, 1887-198\%. Columbia, MO: Missouri Agricultural Experiment Station, University of Missouri.

Manson, S., J. Schroeder, D. V. Riper, and S. Ruggles (2018). IPUMS national historical geographic information system: version 13.0. http://doi.org/10.18128/D050.V13 0 .

Marco, A. C., M. Carley, S. Jackson, and A. F. Myers (2015, June). The USPTO historical patent data files: two centuries of invention. Unpublished, USPTO Economic Working Paper No. 2015-1.

Martin, D. D. (1960). The lamp in the desert: the story of the University of Arizona. Tucson, AZ: The University of Arizona Press.

McMath Jr., R. C., R. H. Bayor, J. E. Brittain, L. Foster, A. W. Giebelhaus, and G. M. Reed (1985). Engineering the new south: Georgia Tech, 1885-1985. Athens, GA: The University of Georgia Press.

Montgomery, J. R., S. J. Folmsbee, and L. S. Greene (1984). To foster knowledge: a history of the University of Tennessee, 1794-1970. Knoxville, TN: The University of Tennessee Press.

Moscona, J. (2019). Downstream effects of research incentives: evidence from agricultural innovation. Unpublished, MIT.

Moser, P. and P. W. Rhode (2012). Did plant patents create the American rose? In J. Lerner and S. Stern (Eds.), The Rate and Direction of Inventive Activity Revisited, pp. 413-438. Chicago: University of Chicago Press.

Mowery, D. C. and N. Rosenberg (1998). Paths of innovation: technological change in 20thcentury American. Cambridge: Cambridge University Press.

Mowery, D. C. and B. N. Sampat (2001, August). University patents and patent policy debates in the USA, 1925-1980. Industrial and Corporate Change 10(3), 781-814.

Olmstead, A. L. and P. W. Rhode (2008). Creating abundance: biological innovation and American agricultural development. Cambridge: Cambridge University Press.

O'Mara, M. P. (2005). Cities of knowledge: Cold War science and the search for the next Silicon Valley. Princeton, NJ: Princeton University Press.

Proctor, S. and W. Langley (1986). Gator history: a pictorial history of the University of Florida. Gainesville, FL: South Star Publishing Company. 
Reel, J. V. (2011). The high seminary: a history of the Clemson Agricultural College of South Carolina, 1889-1964, Volume 1. Clemson, SC: Clemson University Digital Press.

Rees, D. and A. Walsworth (1989). The University of Missouri: 150 years. Marceline, MO: Walsworth Publishing Company.

Reynolds, J. H. and D. Y. Thomas (1910). History of the University of Arkansas. Fayetteville, AR: University of Arkansas.

Roberts, C. N. (1946). History of the University of Missouri School of Mines and Metallurgy, 1871-1946.

Rosenberg, N. and R. R. Nelson (1994, May). American universities and technical advance in industry. Research Policy 23(3), 323-348.

Ross, E. D. (1958). The land-grant idea at Iowa State College: a centennial trial balance, 1858-1958. Ames, IA: The Iowa State College Press.

Sansing, D. G. (1999). The University of Mississippi: a sesquicentenniel history. Oxford, MS: University Press of Mississippi.

Scheuring, A. F. (2001). Abundant harvest: the history of the University of California, Davis. Davis, CA: UC Davis History Project.

Smith, D. C. (1979). The first century: a history of the University of Maine, 1865-1965. Orono, ME: University of Maine at Orono Press.

Solberg, W. U. (1968). The University of Illinois: 1867-1894: an intellectual and cultural history. Urbana, IL: University of Illinois Press.

Sorber, N. M. (2018). Land-grant colleges and popular revolt: the origins of the Morrill Act and the reform of higher education. Ithaca, NY: Cornell University Press.

Turner, F. H. (1932). Misconceptions concerning the early history of the University of Illinois. In Transactions for the Year 1932: Proceedings of the Annual Meeting, Papers Presented at that Time, Contributions to State History, Volume 39. Illinois State Historical Library.

Wagoner, J. J. (1970). Arizona Territory, 1863-1912: a political history. University of Arizona Press.

Willis, J. F. (2009). Southern Arkansas University: the mulerider school's centennial history, 1909-2009. Bloomington, IN: Xlibris Corporation.

Wright, B. D. (2012, December). Grand missions of agricultural innovation. Research Policy $41(10), 1716-1728$. 


\section{Graphs}

Figure 1: Land Grant College and Runner-Up Counties

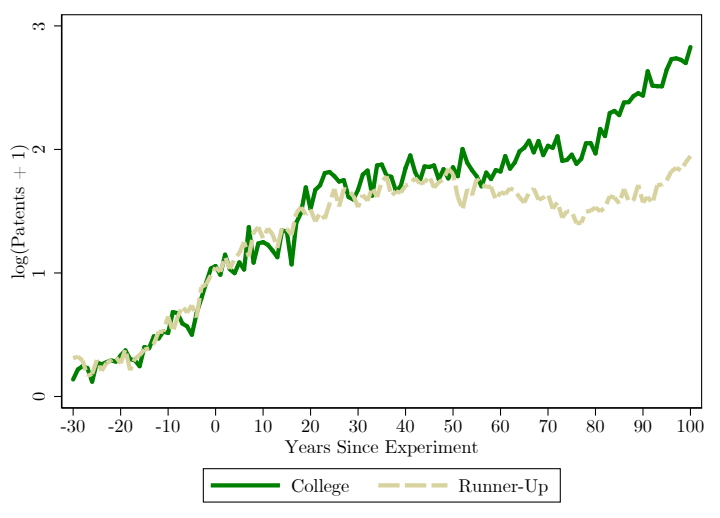

(a) $\log ($ Patents +1$)$

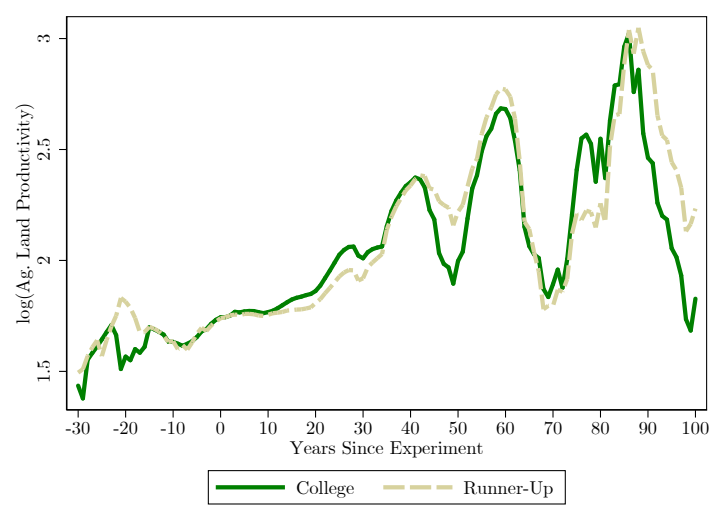

(c) $\log ($ Ag.Yields $)$

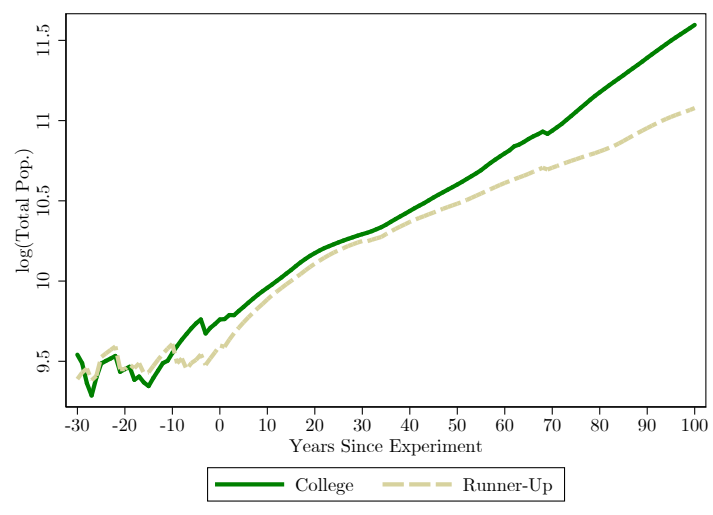

(b) $\log$ (Population)

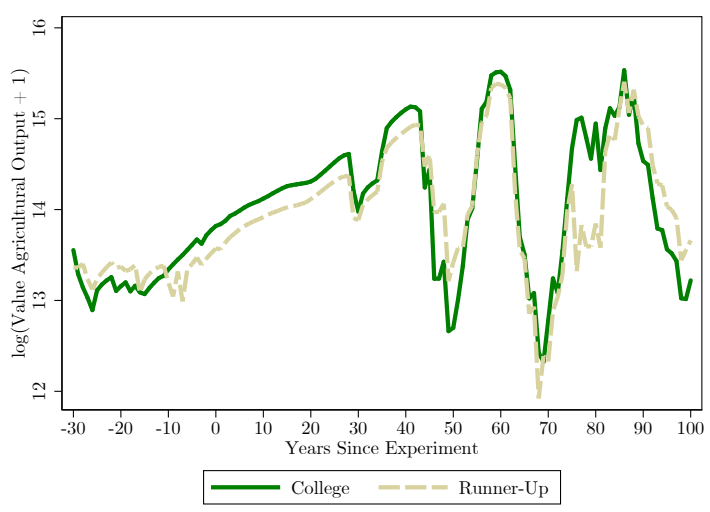

(d) $\log$ (Ag.Output)

Notes: Plots of various outcome variables in land grant college (green solid lines) and runner-up (gold dashed lines) counties. The $\mathrm{x}$-axis shows the number of years since the land grant college experiment. The year of the college experiment is normalized to year 0 . 
Figure 2: Land Grant College and Runner-Up Counties

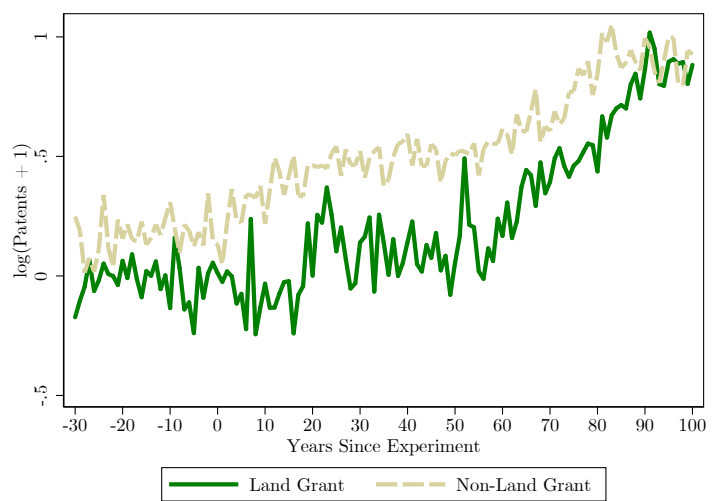

(a) $\log ($ Patents +1$)$

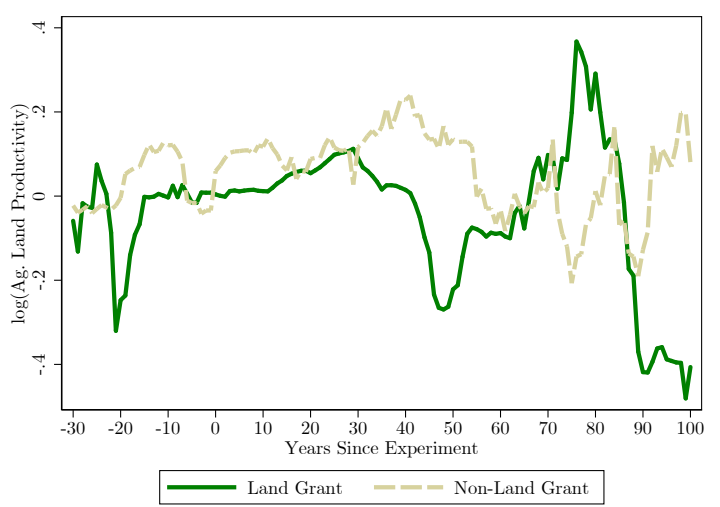

(c) $\log ($ Ag.Yields $)$

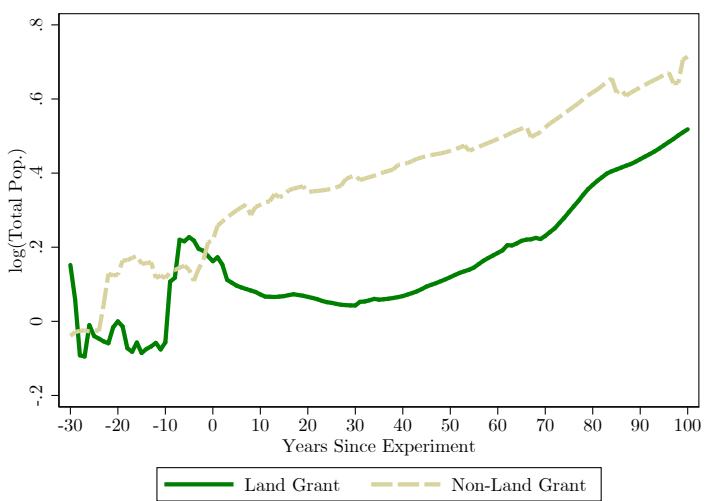

(b) $\log$ (Population)

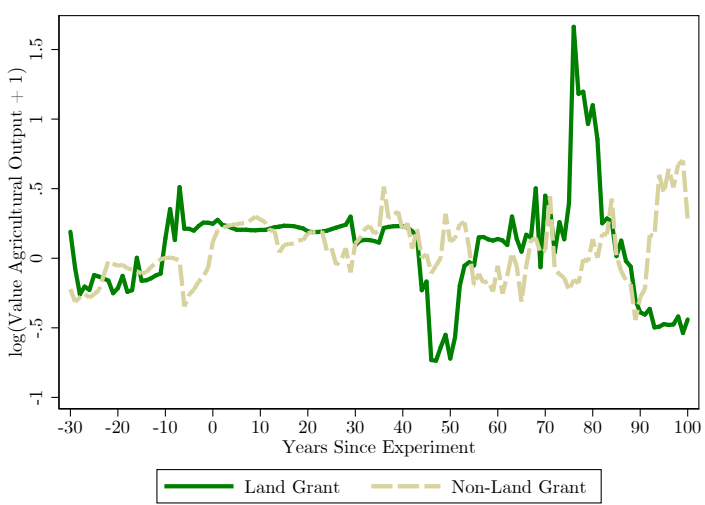

(d) $\log ($ Ag.Output $)$

Notes: Plots of the difference between college and runner-up counties for various outcome variables for land grant colleges (green solid lines) and non-land grant colleges (gold dashed lines). The x-axis shows the number of years since the land grant college experiment. The year of the college experiment is normalized to year 0 . 
Figure 3: Land Grant College and Runner-Up Counties

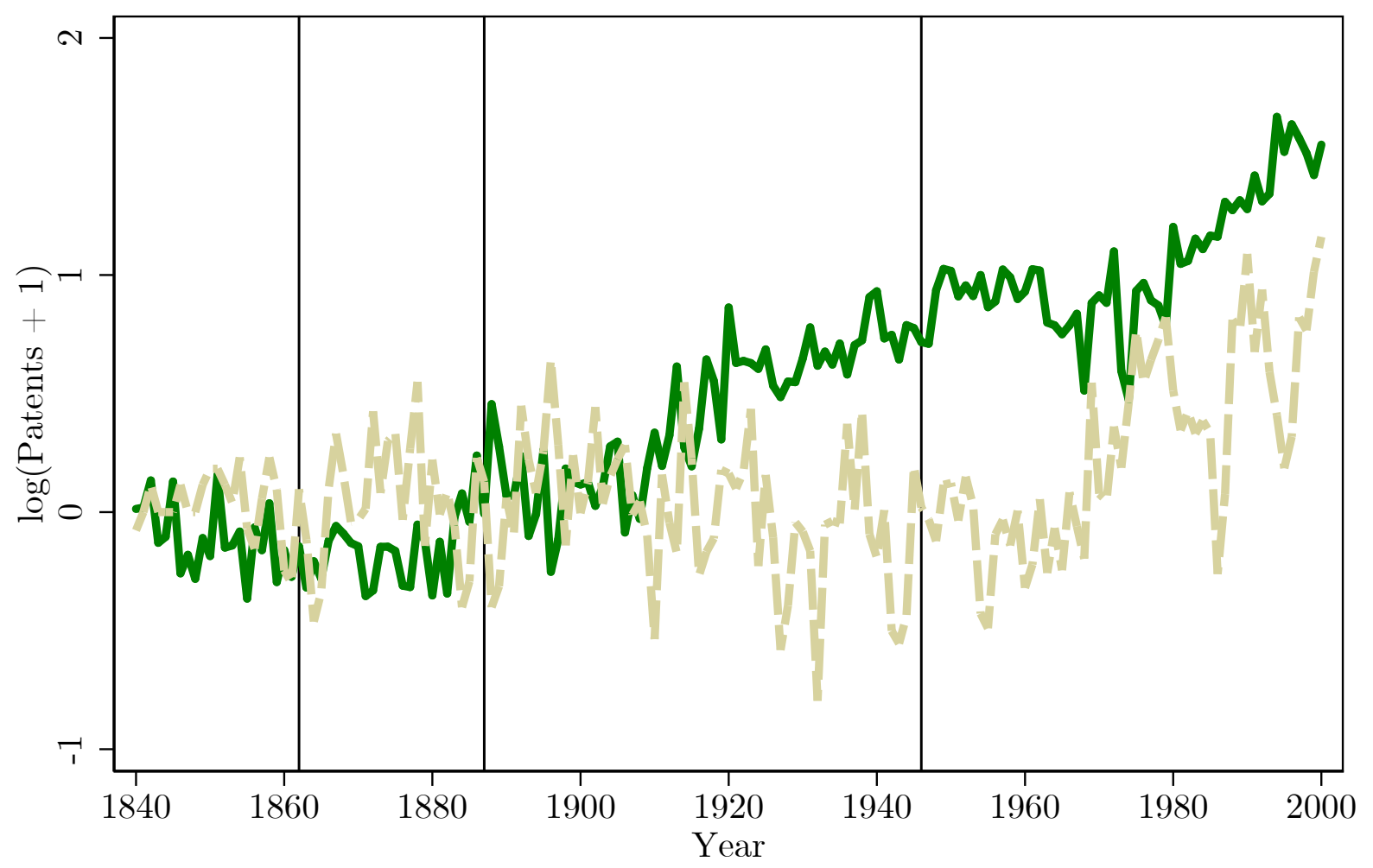

\section{Land Grant $=-$ Non-Land Grant}

Figure 4: $\log ($ Patents +1$)$

Notes: Plot of the difference in logged patenting between college and runner-up counties for land grant colleges (green solid lines) and non-land grant colleges (gold dashed lines) established between 1860 and 1870. The x-axis shows calendar years. 


\section{Tables}

Table 1: List of Land Grant College Experiments

\begin{tabular}{|c|c|c|c|c|c|}
\hline & College & County & State & Runner-Up Counties & Year Established \\
\hline 1 & Pennsylvania State University & Centre & Pennsylvania & Blair & 1855 \\
\hline 2 & University of California Berkeley & Alameda & California & Contra Costa; Napa & 1857 \\
\hline 3 & Kansas State University & Riley & Kansas & Shawnee & 1863 \\
\hline 4 & Cornell University & Tompkins & New York & Onondaga; Seneca; Schuyler & 1865 \\
\hline 5 & University of Maine & Penobscot & Maine & Sagadahoc & 1866 \\
\hline 6 & University of Wisconsin & Dane & Wisconsin & Fond du Lac & 1866 \\
\hline 7 & University of Illinois & Champaign & Illinois & Morgan; McLean; Logan & 1867 \\
\hline 8 & West Virginia University & Monongalia & West Virginia & Greenbrier; Kanawha & 1867 \\
\hline 9 & Oregon State University & Benton & Oregon & Marion & 1868 \\
\hline 10 & Purdue University & Tippecanoe & Indiana & Monroe; Hancock; Marion & 1869 \\
\hline 11 & University of Tennessee & Knox & Tennessee & Rutherford & 1869 \\
\hline 12 & Louisiana State University & East Baton Rouge & Louisiana & East Feliciana; Bienville & 1870 \\
\hline 13 & Texas A and M University & Brazos & Texas & Austin; Grimes & 1871 \\
\hline 14 & University of Arkansas & Washington & Arkansas & Independence & 1871 \\
\hline 15 & Auburn University & Lee & Alabama & Tuscaloosa; Lauderdale & 1872 \\
\hline 16 & Virginia Polytechnic Institute & Montgomery & Virginia & Albemarle; Rockbridge & 1872 \\
\hline 17 & North Dakota State University & Cass & North Dakota & Stutsman; Burleigh & 1883 \\
\hline 18 & University of Arizona & Pima & Arizona & Pinal & 1885 \\
\hline 19 & University of Nevada & Washoe & Nevada & Carson City & 1885 \\
\hline 20 & North Carolina State University & Wake & North Carolina & Lenoir; Mecklenburg & 1886 \\
\hline 21 & University of Wyoming & Albany & Wyoming & Laramie; Uinta & 1886 \\
\hline 22 & Utah State University & Cache & Utah & Weber & 1888 \\
\hline 23 & Clemson University & Pickens & South Carolina & Richland & 1889 \\
\hline 24 & New Mexico State University & Dona Ana & New Mexico & San Miguel & 1889 \\
\hline 25 & University of Idaho & Latah & Idaho & Bonneville & 1889 \\
\hline 26 & University of New Hampshire & Strafford & New Hampshire & Belknap & 1891 \\
\hline 27 & Washington State University & Whitman & Washington & Yakima & 1891 \\
\hline 28 & University of Florida & Alachua & Florida & Columbia & 1905 \\
\hline 29 & University of California Davis & Yolo & California & Contra Costa; Solano & 1906 \\
\hline
\end{tabular}

Notes: List of land grant college experiments in the sample, along with the winning county and state, the runner-up counties, and the year in which the site selection decision took place.

Table 2: Summary Statistics of Land Grant College Experiments

\begin{tabular}{lcccccc}
\hline & N & Mean & S.D. & Min & Median & Max \\
\hline \# Runner-Up Counties & 29 & 1.55 & 0.69 & 1.00 & 1.00 & 3.00 \\
Distance to College & 45 & 150.38 & 111.88 & 30.31 & 109.28 & 553.35 \\
Year Established & 29 & 1877.28 & 13.28 & 1855.00 & 1872.00 & 1906.00
\end{tabular}

Notes: Number of runner-up counties, average distance from the runner-up counties to the college site, and experiment year for the land grant college experiments in the sample. 
Table 3: Differences-in-Differences Results Comparing Land Grant College Counties to Runner-Up Counties

(a) Innovation and Population Outcomes

\begin{tabular}{|c|c|c|c|c|c|c|}
\hline & $\log ($ Patents +1$)$ & $\log ($ Ag. Patents +1$)$ & Frac. Ag. Patents & New Wheat Variety & $\log$ (Total Pop.) & $\log$ (Frac. Urban) \\
\hline CollegeCounty $*$ PostCollege & $\begin{array}{l}0.539^{* *} \\
(0.193)\end{array}$ & $\begin{array}{c}0.0857 \\
(0.0624)\end{array}$ & $\begin{array}{c}0.00246 \\
(0.0196)\end{array}$ & $\begin{array}{c}0.0168^{* *} \\
(0.00605)\end{array}$ & $\begin{array}{l}0.0966 \\
(0.199)\end{array}$ & $\begin{array}{c}0.00319 \\
(0.0304)\end{array}$ \\
\hline PostCollege & $\begin{array}{l}0.0970 \\
(0.172)\end{array}$ & $\begin{array}{c}0.105 \\
(0.0627)\end{array}$ & $\begin{array}{c}0.0228 \\
(0.0147)\end{array}$ & $\begin{array}{c}-0.00711^{*} \\
(0.00282)\end{array}$ & $\begin{array}{c}0.287 \\
(0.157)\end{array}$ & $\begin{array}{c}0.0264 \\
(0.0232)\end{array}$ \\
\hline Num. Counties $\times$ Years & 13141 & 13141 & 9745 & 6639 & 12449 & 9477 \\
\hline Adj. r-Sqr. & 0.721 & 0.314 & 0.0461 & 0.00778 & 0.799 & 0.702 \\
\hline
\end{tabular}

Standard errors in parentheses

${ }^{*} p<0.05,{ }^{* *} p<0.01,{ }^{* * *} p<0.001$

(b) Agricultural Outcomes

\begin{tabular}{lcccc}
\hline & $\log ($ Ag. Land Productivity) & $\log$ (Value Agricultural Output +1$)$ & $\log ($ Value Crops +1$)$ & $\log ($ Value Livestock Products +1$)$ \\
\hline CollegeCounty * PostCollege & 0.0998 & 0.156 & 0.127 & $(0.331)$ \\
& $(0.118)$ & $(0.286)$ & 0.0419 & $(0.385)$ \\
PostCollege & $-0.177^{*}$ & 0.314 & $(0.280)$ & $(0.628$ \\
& $(0.0837)$ & $(0.222)$ & 12190 & 12190 \\
\hline Num. Counties $\times$ Years & 11780 & 12190 & 0.956 & 0.938 \\
Adj. r-Sqr. & 0.914 & 0.923 & & \\
\hline
\end{tabular}

Standard errors in parentheses

${ }^{*} p<0.05,{ }^{* *} p<0.01,{ }^{* * *} p<0.001$

Notes: Differences-in-differences regression results comparing land grant college counties to runner-up counties before and after establishing each college. Panel (a) uses innovation and population outcomes as the dependent variables. Panel (b) uses agricultural yield and output as the dependent variables. All regressions include county and year fixed effects. Standard errors are clustered at the county level. 
Table 4: Triple Differences Results Comparing the Land Grant to Non-Land Grant Colleges

(a) Innovation and Population Outcomes

\begin{tabular}{|c|c|c|c|c|c|c|}
\hline & $\log ($ Patents +1$)$ & $\log ($ Ag. Patents +1$)$ & Frac. Ag. Patents & New Wheat Variety & $\log$ (Total Pop.) & $\log$ (Frac. Urban) \\
\hline College $*$ Post-College $*$ Land Grant & $\begin{array}{c}-0.0934 \\
(0.263)\end{array}$ & $\begin{array}{c}-0.00639 \\
(0.0757)\end{array}$ & $\begin{array}{c}0.00930 \\
(0.0257)\end{array}$ & $\begin{array}{c}0.0157^{*} \\
(0.00640)\end{array}$ & $\begin{array}{l}-0.385 \\
(0.262)\end{array}$ & $\begin{array}{l}-0.0616 \\
(0.0433)\end{array}$ \\
\hline CollegeCounty * PostCollege & $\begin{array}{c}0.634^{* * *} \\
(0.183)\end{array}$ & $\begin{array}{c}0.0926^{*} \\
(0.0426)\end{array}$ & $\begin{array}{c}-0.00842 \\
(0.0170)\end{array}$ & $\begin{array}{c}0.00118 \\
(0.00206)\end{array}$ & $\begin{array}{l}0.487^{* *} \\
(0.164)\end{array}$ & $\begin{array}{l}0.0649^{*} \\
(0.0310)\end{array}$ \\
\hline Post-College * Land Grant & $\begin{array}{c}0.209 \\
(0.182)\end{array}$ & $\begin{array}{c}0.0798 \\
(0.0570)\end{array}$ & $\begin{array}{c}0.0129 \\
(0.0172)\end{array}$ & $\begin{array}{c}-0.000826 \\
(0.00164)\end{array}$ & $\begin{array}{c}0.216 \\
(0.182)\end{array}$ & $\begin{array}{c}0.0438 \\
(0.0267)\end{array}$ \\
\hline PostCollege & $\begin{array}{l}-0.126 \\
(0.107)\end{array}$ & $\begin{array}{c}-0.00841 \\
(0.0333)\end{array}$ & $\begin{array}{l}0.00906 \\
(0.0116)\end{array}$ & $\begin{array}{c}-0.00103 \\
(0.00168)\end{array}$ & $\begin{array}{l}0.00980 \\
(0.0966)\end{array}$ & $\begin{array}{r}-0.00970 \\
(0.0164)\end{array}$ \\
\hline Num. Counties $\times$ Years & 34911 & 34911 & 24115 & 17760 & 33541 & 25601 \\
\hline Adj. r-Sqr. & 0.724 & 0.297 & 0.0527 & 0.00408 & 0.803 & 0.734 \\
\hline
\end{tabular}

Standard errors in parentheses

${ }^{*} p<0.05,{ }^{* *} p<0.01,{ }^{* * *} p<0.001$

(b) Agricultural Outcomes

\begin{tabular}{|c|c|c|c|c|}
\hline & $\log$ (Ag. Land Productivity) & $\log ($ Value Agricultural Output +1$)$ & $\log ($ Value Crops +1$)$ & $\log ($ Value Livestock Products +1$)$ \\
\hline College $*$ Post-College $*$ Land Grant & $\begin{array}{l}0.0538 \\
(0.144)\end{array}$ & $\begin{array}{c}-0.0462 \\
(0.366)\end{array}$ & $\begin{array}{c}-0.0544 \\
(0.432)\end{array}$ & $\begin{array}{l}-0.146 \\
(0.472)\end{array}$ \\
\hline CollegeCounty $*$ PostCollege & $\begin{array}{c}0.0337 \\
(0.0985)\end{array}$ & $\begin{array}{c}0.203 \\
(0.219)\end{array}$ & $\begin{array}{c}0.182 \\
(0.275)\end{array}$ & $\begin{array}{c}0.123 \\
(0.265)\end{array}$ \\
\hline Post-College * Land Grant & $\begin{array}{l}-0.177^{*} \\
(0.0751)\end{array}$ & $\begin{array}{c}-0.0331 \\
(0.199)\end{array}$ & $\begin{array}{c}-0.0922 \\
(0.245)\end{array}$ & $\begin{array}{c}0.497 \\
(0.265)\end{array}$ \\
\hline PostCollege & $\begin{array}{c}0.108 \\
(0.0555)\end{array}$ & $\begin{array}{c}0.227^{*} \\
(0.0953)\end{array}$ & $\begin{array}{c}0.157 \\
(0.121)\end{array}$ & $\begin{array}{l}0.0103 \\
(0.119)\end{array}$ \\
\hline Num. Counties $\times$ Years & 32092 & 33312 & 33312 & 33312 \\
\hline Adj. r-Sqr. & 0.918 & 0.926 & 0.966 & 0.947 \\
\hline
\end{tabular}

Standard errors in parentheses

${ }^{*} p<0.05,{ }^{* *} p<0.01,{ }^{* * *} p<0.001$

Notes: Triple differences regression results comparing college counties to runner-up counties before and after establishing each college for land grant and non-land grant colleges. Panel (a) uses innovation and population outcomes as the dependent variables. Panel (b) uses agricultural yield and output as the dependent variables. All regressions include county and year fixed effects. Standard errors are clustered at the county level. 
Table 5: Comparing Land Grant College Counties to Runner-Up Counties following Several Pieces of Legislation

(a) Innovation and Population Outcomes

\begin{tabular}{lccccc}
\hline \hline & $\log ($ Patents +1$)$ & $\log ($ Ag. Patents +1$)$ & Frac. Ag. Patents & $\log ($ Total Pop.) & $\log ($ Frac. Urban) \\
\hline College * Post-Morrill Act & -0.0165 & 0.108 & 0.0643 & -0.0151 & -0.0202 \\
& $(0.255)$ & $(0.152)$ & $(0.0453)$ & $(0.210)$ & $(0.0330)$ \\
College * Post-Hatch Act & 0.466 & 0.0238 & 0.0389 & 0.112 & 0.0182 \\
& $(0.340)$ & $(0.0914)$ & $(0.0305)$ & $(0.289)$ & $(0.0420)$ \\
College * Post-World War II & 0.646 & 0.179 & -0.00594 & $0.538^{* *}$ & 0.0911 \\
& $(0.332)$ & $(0.0914)$ & $(0.0100)$ & $(0.156)$ & $(0.0587)$ \\
\hline Num. Counties $\times$ Years & 4451 & 4451 & 3526 & 4378 & 3538 \\
Adj. r-Sqr. & 0.747 & 0.304 & 0.0582 & 0.846 & 0.744 \\
\hline \hline
\end{tabular}

Standard errors in parentheses

${ }^{*} p<0.05,{ }^{* *} p<0.01,{ }^{* * *} p<0.001$

(b) Agricultural Outcomes

\begin{tabular}{|c|c|c|c|c|}
\hline & $\log$ (Ag. Land Productivity) & $\log ($ Value Agricultural Output +1$)$ & $\log ($ Value Crops +1$)$ & $\log ($ Value Livestock Products +1$)$ \\
\hline College $*$ Post-Morrill Act & $\begin{array}{l}-0.0765 \\
(0.0810)\end{array}$ & $\begin{array}{l}-0.128 \\
(0.302)\end{array}$ & $\begin{array}{l}-0.107 \\
(0.264)\end{array}$ & $\begin{array}{c}0.228 \\
(0.423)\end{array}$ \\
\hline College $*$ Post-Hatch Act & $\begin{array}{c}-0.0280 \\
(0.137)\end{array}$ & $\begin{array}{c}-0.0222 \\
(0.357)\end{array}$ & $\begin{array}{r}-0.0692 \\
(0.376)\end{array}$ & $\begin{array}{c}-0.161 \\
(0.324)\end{array}$ \\
\hline College * Post-World War II & $\begin{array}{c}0.0459 \\
(0.0800)\end{array}$ & $\begin{array}{l}0.0971 \\
(0.261)\end{array}$ & $\begin{array}{c}0.106 \\
(0.426)\end{array}$ & $\begin{array}{l}0.0909 \\
(0.238)\end{array}$ \\
\hline $\begin{array}{l}\text { Num. Counties } \times \text { Years } \\
\text { Adj. r-Sqr. }\end{array}$ & $\begin{array}{l}4188 \\
0.951\end{array}$ & $\begin{array}{l}4398 \\
0.947\end{array}$ & $\begin{array}{l}4398 \\
0.973\end{array}$ & $\begin{array}{l}4398 \\
0.950\end{array}$ \\
\hline
\end{tabular}

Standard errors in parentheses

${ }^{*} p<0.05,{ }^{* *} p<0.01,{ }^{* * *} p<0.001$

Notes: Triple differences regression results comparing college counties to runner-up counties before and after several major land grant-related pieces of legislation for the cohort of land grant and non-land grant colleges established between 1860 and 1870. Panel (a) uses innovation and population outcomes as the dependent variables. Panel (b) uses agricultural yield and output as the dependent variables. All regressions include county and year fixed effects. Standard errors are clustered at the county level. 
Table 6: Comparing the Land Grant to Non-Land Grant Colleges following Several Pieces of Legislation

(a) Innovation and Population Outcomes

\begin{tabular}{lccccc}
\hline & $\log ($ Patents +1$)$ & $\log ($ Ag. Patents + 1) & Frac. Ag. Patents & $\log$ (Total Pop.) & $\log$ (Frac. Urban) \\
\hline College * Post-Morrill Act * Land Grant & -0.149 & 0.149 & -0.0372 & -0.276 & 0.00831 \\
& $(0.347)$ & $(0.146)$ & $(0.0797)$ & $(0.213)$ & $(0.0398)$ \\
& & & -0.0696 & -0.148 & 0.0193 \\
College * Post-Hatch Act * Land Grant & 0.456 & 0.0250 & $(0.0759)$ & $(0.317)$ & $(0.0662)$ \\
& $(0.441)$ & $(0.0932)$ & -0.0131 & 0.246 & 0.0460 \\
College * Post-World War II * Land Grant & 0.365 & 0.165 & $(0.0524)$ & $(0.218)$ & $(0.0846)$ \\
& $(0.407)$ & $(0.107)$ & 5253 & 7227 & 5817 \\
Num. Counties $\times$ Years & 7248 & 7248 & 0.0454 & 0.868 & 0.771 \\
Adj. r-Sqr. & 0.750 & 0.289 & & & \\
\hline \hline
\end{tabular}

Standard errors in parenthese

${ }^{*} p<0.05,{ }^{*} p<0.01,{ }^{* * *} p<0.001$

(b) Agricultural Outcomes

\begin{tabular}{|c|c|c|c|c|}
\hline & $\log$ (Ag. Land Productivity) & $\log ($ Value Agricultural Output +1$)$ & $\log ($ Value Crops +1$)$ & $\log ($ Value Livestock Products +1$)$ \\
\hline College * Post-Morrill Act * Land Grant & $\begin{array}{c}-0.0598 \\
(0.162)\end{array}$ & $\begin{array}{r}-0.0179 \\
(0.481)\end{array}$ & $\begin{array}{c}-0.152 \\
(0.398)\end{array}$ & $\begin{array}{c}0.179 \\
(0.692)\end{array}$ \\
\hline College * Post-Hatch Act * Land Grant & $\begin{array}{c}-0.0199 \\
(0.144)\end{array}$ & $\begin{array}{c}0.153 \\
(0.480)\end{array}$ & $\begin{array}{c}0.126 \\
(0.505)\end{array}$ & $\begin{array}{l}0.0783 \\
(0.462)\end{array}$ \\
\hline College * Post-World War II * Land Grant & $\begin{array}{c}0.0941 \\
(0.0953)\end{array}$ & $\begin{array}{c}0.302 \\
(0.344)\end{array}$ & $\begin{array}{c}0.388 \\
(0.679)\end{array}$ & $\begin{array}{c}0.145 \\
(0.289)\end{array}$ \\
\hline $\begin{array}{l}\text { Num. Counties } \times \text { Years } \\
\text { Adj. r-Sgr. }\end{array}$ & $\begin{array}{c}6947 \\
0.956\end{array}$ & $\begin{array}{l}7267 \\
0.957\end{array}$ & $\begin{array}{r}7267 \\
0.976\end{array}$ & $\begin{array}{l}7267 \\
0.956\end{array}$ \\
\hline
\end{tabular}

Standard errors in parentheses

${ }^{*} p<0.05,{ }^{* *} p<0.01,{ }^{* * *} p<0.001$

Notes: Differences-in-differences regression results comparing land grant college counties to runner-up counties before and after several major land grant-related pieces of legislation for the cohort of colleges established before 1870. Panel (a) uses innovation and population outcomes as the dependent variables. Panel (b) uses agricultural yield and output as the dependent variables. All regressions include county and year fixed effects. Standard errors are clustered at the county level. 


\section{A The Non-Land Grant College Sample}

Table A1

\begin{tabular}{|c|c|c|c|c|c|}
\hline & College & County & State & Runner-Up Counties & Year Established \\
\hline 1 & University of Mississippi & Lafayette & Mississippi & $\begin{array}{c}\text { Attala; Monroe; Winston; Harrison; Montgomery; } \\
\text { Rankin }\end{array}$ & 1841 \\
\hline 2 & Eastern Michigan University & Washtenaw & Michigan & Jackson & 1849 \\
\hline 3 & The College of New Jersey & Mercer & New Jersey & Essex; Burlington; Middlesex & 1855 \\
\hline 4 & University of South Dakota & Clay & South Dakota & Yankton; Bon Homme & 1862 \\
\hline 5 & University of Kansas & Douglas & Kansas & Shawnee & 1863 \\
\hline 6 & Lincoln College (IL) & Logan & Illinois & Macon; Warrick; Edgar & 1864 \\
\hline 7 & Southern Illinois University & Jackson & Illinois & Jefferson; Washington; Perry; Clinton; Marion & 1869 \\
\hline 8 & Mercer University & Bibb & Georgia & Spalding & 1870 \\
\hline 9 & Missouri University of Science and Technology & Phelps & Missouri & Iron & 1870 \\
\hline 10 & University of Oregon & Lane & Oregon & Linn; Polk; Washington & 1872 \\
\hline 11 & University of Colorado & Boulder & Colorado & Fremont & 1874 \\
\hline 12 & University of Texas Austin & Travis & Texas & Smith & 1881 \\
\hline 13 & University of Texas Medical Branch & Galveston & Texas & Harris & 1881 \\
\hline 14 & University of North Dakota & Grand Forks & North Dakota & Stutsman; Burleigh & 1883 \\
\hline 15 & Arizona State University & Maricopa & Arizona & Pinal & 1885 \\
\hline 16 & Georgia Institute of Technology & Fulton & Georgia & Bibb; Greene; Baldwin; Clarke & 1886 \\
\hline 17 & Kentucky State University & Franklin & Kentucky & Daviess; Christian; Warren; Boyle; Fayette & 1886 \\
\hline 18 & New Mexico Tech & Socorro & New Mexico & San Miguel & 1889 \\
\hline 19 & University of New Mexico & Bernalillo & New Mexico & San Miguel & 1889 \\
\hline 20 & Alabama Agricultural and Mechanical University & Madison & Alabama & Montgomery & 1891 \\
\hline 21 & North Carolina A and T University & Guilford & North Carolina & Forsyth; Durham; New Hanover; Alamance & 1892 \\
\hline 22 & Northern Illinois University & DeKalb & Illinois & Winnebago & 1895 \\
\hline 23 & Western Illinois University & McDonough & Illinois & Hancock; Adams; Mercer; Warren; Schuyler & 1899 \\
\hline 24 & University of Nebraska at Kearney & Buffalo & Nebraska & Valley; Custer & 1903 \\
\hline 25 & Western Michigan University & Kalamazoo & Michigan & Allegan; Barry & 1903 \\
\hline 26 & Georgia Southern College & Bulloch & Georgia & Tattnall; Emanuel & 1906 \\
\hline 27 & East Carolina University & Pitt & North Carolina & Beaufort; Lenoir; Edgecombe & 1907 \\
\hline 28 & Middle Tennessee State University & Rutherford & Tennessee & Montgomery & 1909 \\
\hline 29 & Western State Colorado University & Gunnison & Colorado & Mesa; Garfield & 1909 \\
\hline 30 & Arkansas Tech University & Pope & Arkansas & Franklin; Conway; Sebastian & 1910 \\
\hline 31 & Bowling Green State University & Wood & Ohio & Henry; Van Wert; Sandusky & 1910 \\
\hline 32 & Kent State University & Portage & Ohio & Trumbull & 1910 \\
\hline 33 & Southern Arkansas University & Columbia & Arkansas & Hempstead; Ouachita; Polk & 1910 \\
\hline 34 & Southern Mississippi University & Forrest & Mississippi & Hinds; Jones & 1910 \\
\hline 35 & Texas Christian University & Tarrant & Texas & Dallas & 1910 \\
\hline 36 & Southern Methodist University & Dallas & Texas & Tarrant & 1911 \\
\hline 37 & High Point University & Guilford & North Carolina & Alamance & 1921 \\
\hline 38 & Texas Tech & Lubbock & Texas & Scurry; Nolan & 1923 \\
\hline 39 & Maine Maritime Academy & Hancock & Maine & Sagadahoc & 1941 \\
\hline 40 & US Merchant Marine Academy & Nassau & New York & Bristol & 1941 \\
\hline 41 & US Air Force Academy & El Paso & Colorado & Madison; Walworth & 1954 \\
\hline
\end{tabular}

Notes: List of non-land grant college experiments in the sample, along with the winning county and state, the runner-up counties, and the year in which the site selection decision took place. 
Table A2

\begin{tabular}{lcccccc}
\hline & N & Mean & S.D. & Min & Median & Max \\
\hline \# Runner-Up Counties & 41 & 2.12 & 1.38 & 1.00 & 2.00 & 6.00 \\
Distance to College & 87 & 139.57 & 202.22 & 30.61 & 84.77 & $1,413.28$ \\
Year Established & 41 & 1893.51 & 24.99 & 1841.00 & 1892.00 & 1954.00
\end{tabular}

Notes: Number of runner-up counties, average distance from the runner-up counties to the college site, and experiment year for the non-land grant college experiments in the sample.

\section{B Results with Both "High" and "Low" Quality Col- lege Site Selection Experiments}

In all of the examples described above, I argue that which finalist county receives the college is as good as random assignment. I refer to these cases as "high quality college site selection experiments." Of course, this is not true for all land grant colleges. In many other cases, I am able to identify a set of finalist counties, but I am less confident that the winning county is randomly assigned. I refer to these as "low quality college site selection experiments." To give concrete examples, I am able to locate runner-up counties for Ohio State University, the University of Wisconsin, and the University of Minnesota, but in all of these cases, a review of the historical narrative literature makes clear that these colleges' locations were selected so that the college could be near the state capitol. These same characteristics that drove the site selection decision are likely to be correlated with other outcome variables under study.

Andrews (2019b), using a larger sample that includes both land grant and non-land grant colleges, shows that failing to restrict attention to the high quality site selection experiments overstates the local effect of establishing a new college on local invention. In this 
paper, because my baseline sample consists of only land grant colleges, results are slightly underpowered when restricting attention to the high quality experiments. In this section, I therefore include both the high and low quality site selection experiments to obtain more precise, although possibly inconsistent, estimates. The results are typically qualitatively similar to those in the body of the paper.

Figure A1: Land Grant College and Runner-Up Counties, Including Low Quality Experiments

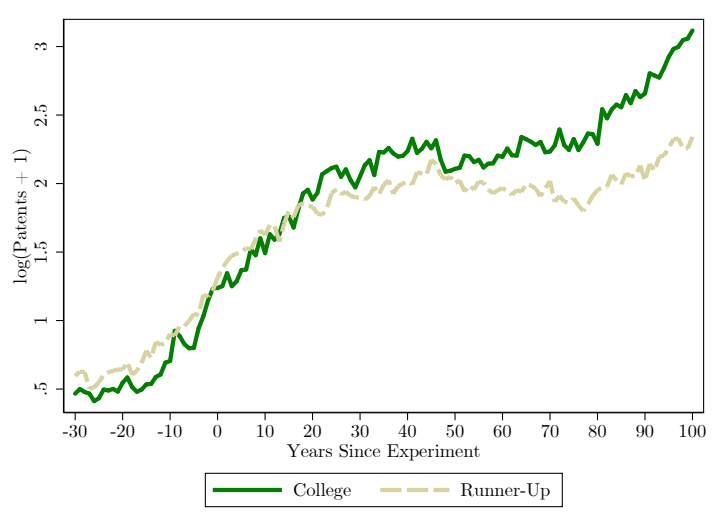

(a) $\log ($ Patents +1$)$

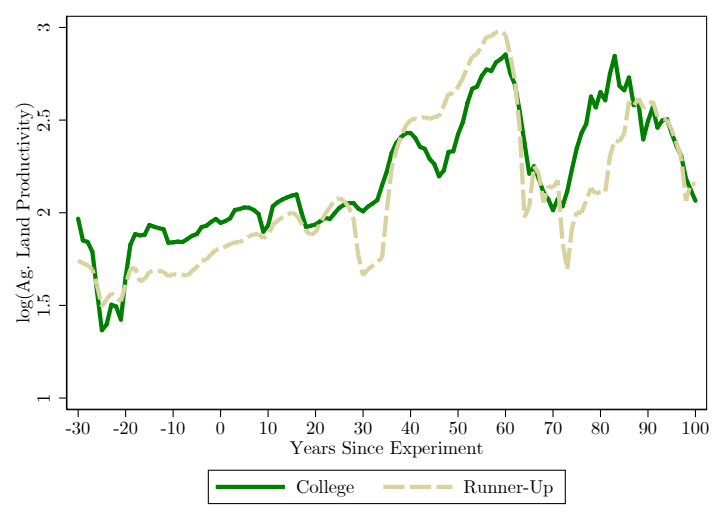

(c) $\log ($ Ag.Yields $)$

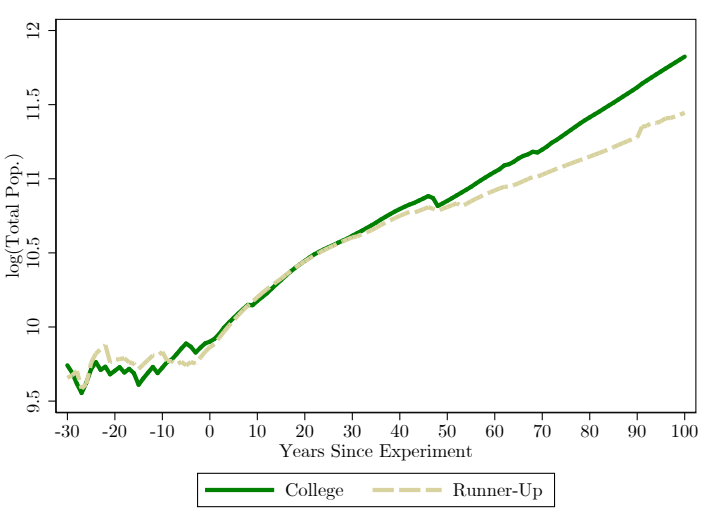

(b) $\log ($ Population $)$

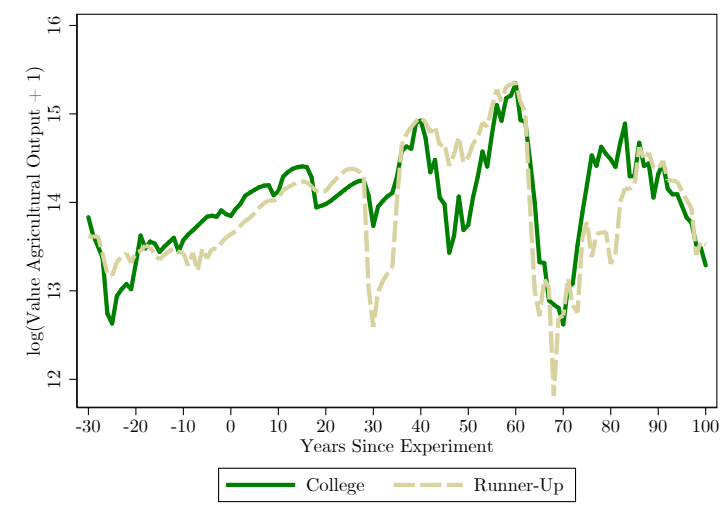

(d) $\log ($ Ag.Output $)$

Notes: Plots of various outcome variables in land grant college (green solid lines) and runner-up (gold dashed lines) counties. The x-axis shows the number of years since the land grant college experiment. The year of the college experiment is normalized to year 0 . All outcome variables are smoothed via local polynomial regression. 
Figure A2: Land Grant College and Runner-Up Counties, Including Low Quality Experiments

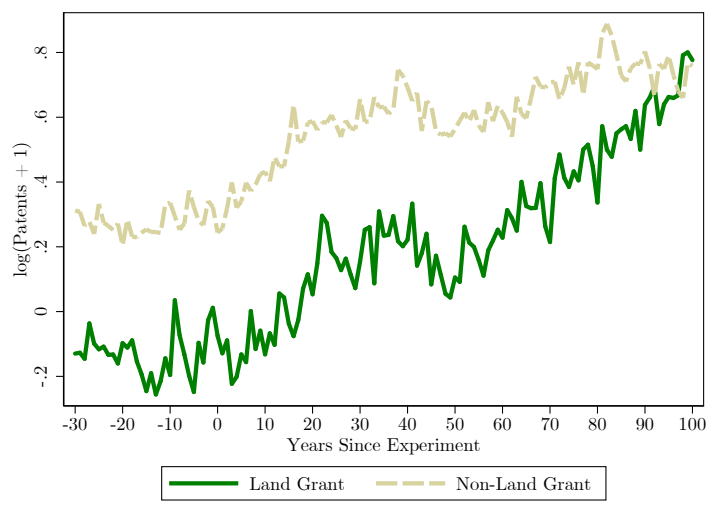

(a) $\log ($ Patents +1$)$

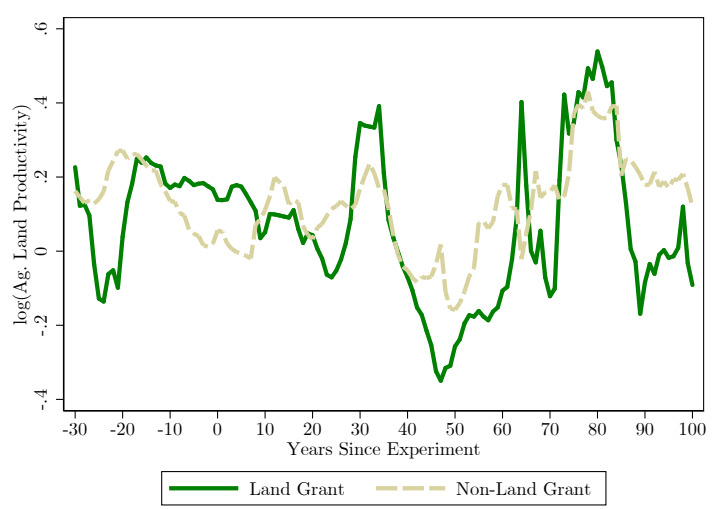

(c) $\log ($ Ag.Yields $)$

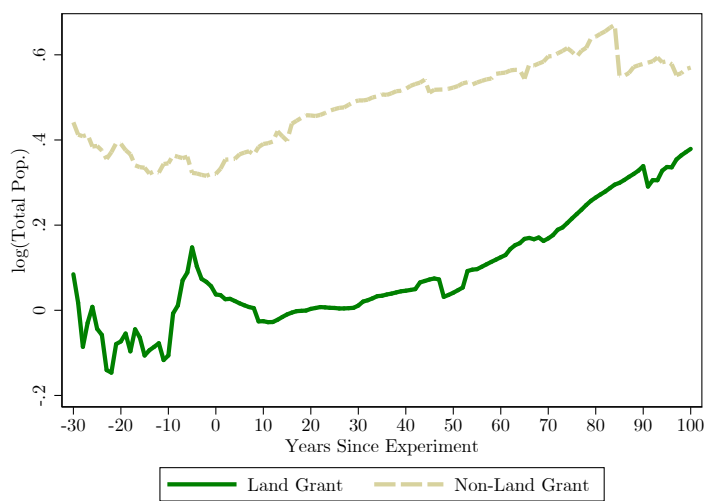

(b) $\log$ (Population)

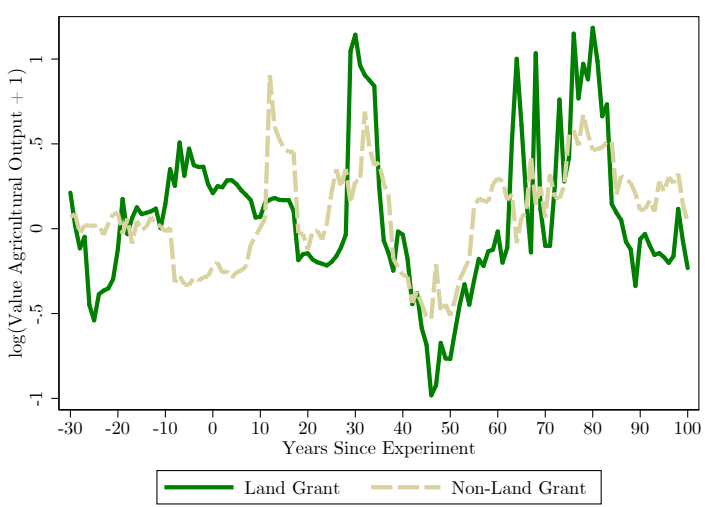

(d) $\log ($ Ag.Output $)$

Notes: Plots of the difference between college and runner-up counties for various outcome variables for land grant colleges (green solid lines) and non-land grant colleges (gold dashed lines). The x-axis shows the number of years since the land grant college experiment. The year of the college experiment is normalized to year 0 . All outcome variables are smoothed via local polynomial regression. 
Figure A3: Land Grant College and Runner-Up Counties, Including Low Quality Experiments

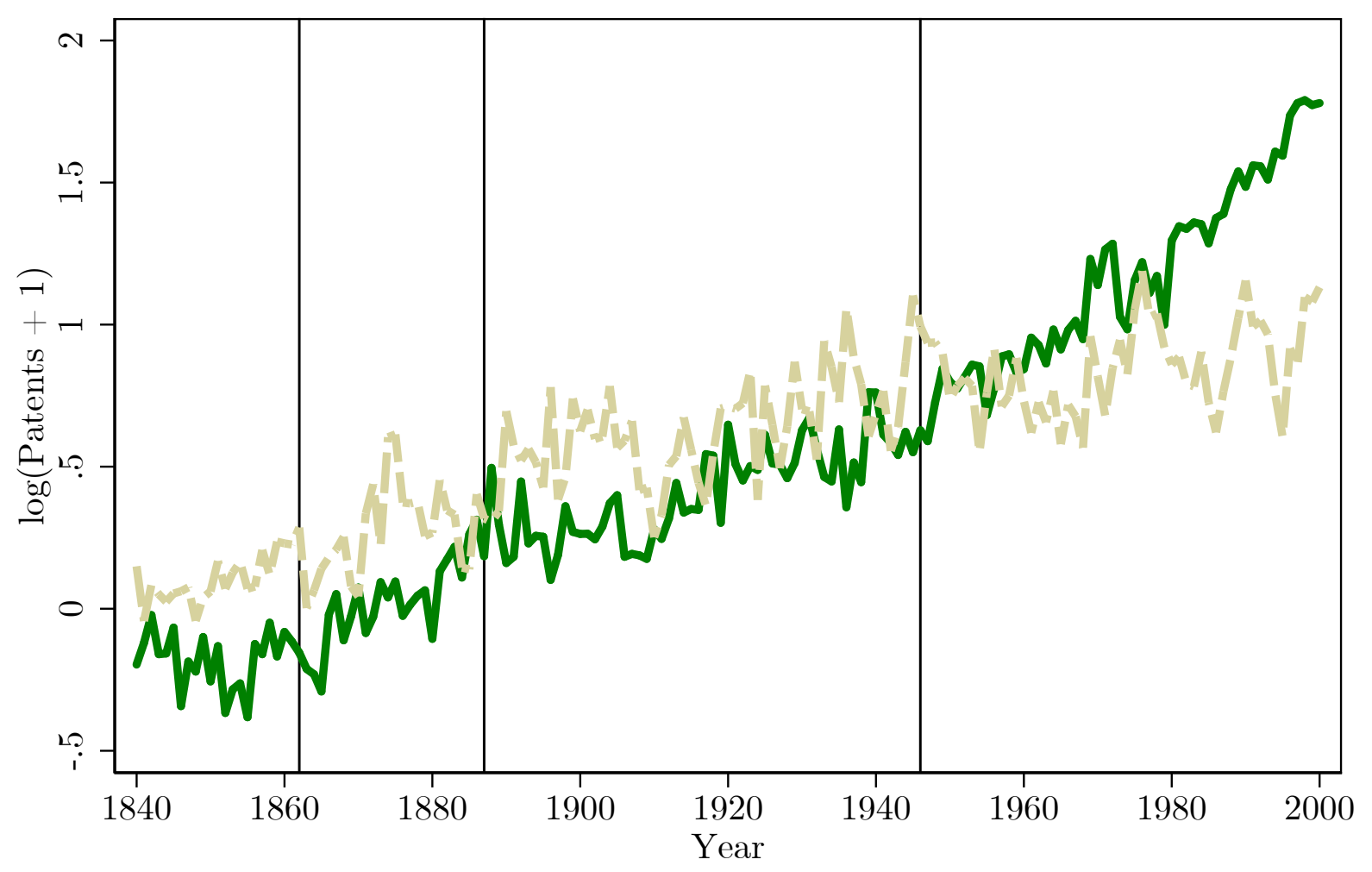

\section{Land Grant $-\ldots$ Non-Land Grant}

Figure A4: $\log ($ Patents +1$)$

Notes: Plot of the difference in logged patenting between college and runner-up counties for land grant colleges (green solid lines) and non-land grant colleges (gold dashed lines) established between 1860 and 1870. The $\mathrm{x}$-axis shows calendar years. The outcome variable is smoothed via local polynomial regression. 
Table A3: List of Land Grant College Experiments, Including Low Quality Experiments

\begin{tabular}{|c|c|c|c|c|c|}
\hline & College & County & State & Runner-Up Counties & Year Established \\
\hline 1 & University of Minnesota & Ramsey & Minnesota & Hennepin & 1851 \\
\hline 2 & Michigan State University & Ingham & Michigan & $\begin{array}{c}\text { Clinton; St. Clair; Newaygo; Ontonagon; Eaton; } \\
\text { Montcalm }\end{array}$ & 1855 \\
\hline 3 & Pennsylvania State University & Centre & Pennsylvania & $\begin{array}{c}\text { Franklin; Perry; Allegheny; Blair; Huntingdon; } \\
\text { Erie }\end{array}$ & 1855 \\
\hline 4 & University of California Berkeley & Alameda & California & Contra Costa; Santa Clara; Napa & 1857 \\
\hline 5 & University of Maryland & Prince George's & Maryland & Montgomery & 1858 \\
\hline 6 & Kansas State University & Riley & Kansas & Leavenworth; Shawnee & 1863 \\
\hline 7 & University of Massachusetts Amherst & Hampshire & Massachusetts & Hampden; Middlesex & 1864 \\
\hline 8 & Cornell University & Tompkins & New York & Schuyler; Onondaga; Seneca & 1865 \\
\hline 9 & Pennsylvania State University & Centre & Pennsylvania & Philadelphia; Union; Crawford; Allegheny; Adams & 1865 \\
\hline 10 & University of Kentucky & Fayette & Kentucky & Mercer & 1865 \\
\hline 11 & University of Vermont & Chittenden & Vermont & Addison; Washington & 1865 \\
\hline 12 & University of Maine & Penobscot & Maine & Sagadahoc & 1866 \\
\hline 13 & University of Wisconsin & Dane & Wisconsin & Fond du Lac & 1866 \\
\hline 14 & University of Illinois & Champaign & Illinois & DuPage; McLean; Morgan; Logan; Cook & 1867 \\
\hline 15 & West Virginia University & Monongalia & West Virginia & $\begin{array}{c}\text { Kanawha; Barbour; Jackson; Brooke; Ritchie; Roane; } \\
\text { Ohio; Doddridge; Lewis; Mason; Taylor; Marshall; } \\
\text { Greenbrier }\end{array}$ & 1867 \\
\hline 16 & Oregon State University & Benton & Oregon & Multnomah; Marion & 1868 \\
\hline 17 & University of Minnesota & Ramsey & Minnesota & Hennepin; McLeod & 1868 \\
\hline 18 & Purdue University & Tippecanoe & Indiana & Marion; Hancock; Monroe & 1869 \\
\hline 19 & University of Tennessee & Knox & Tennessee & Rutherford & 1869 \\
\hline 20 & Louisiana State University & East Baton Rouge & Louisiana & East Feliciana; Rapides; Bienville & 1870 \\
\hline 21 & Ohio State University & Franklin & Ohio & Athens; Hamilton; Butler & 1870 \\
\hline 22 & University of Missouri & Boone & Missouri & Greene; Jackson & 1870 \\
\hline 23 & Texas A and M University & Brazos & Texas & $\begin{array}{c}\text { Grimes; Austin; Limestone; Hays; Travis; Bexar; } \\
\text { McLennan }\end{array}$ & 1871 \\
\hline 24 & University of Arkansas & Washington & Arkansas & Independence & 1871 \\
\hline 25 & Auburn University & Lee & Alabama & Talladega; Tuscaloosa; Lauderdale & 1872 \\
\hline 26 & Virginia Polytechnic Institute & Montgomery & Virginia & $\begin{array}{l}\text { Fredericksburg City; Rockbridge; Chesterfield; } \\
\text { Washington; Prince Edward; Albemarle; Hanover; } \\
\text { Roanoke; Shenandoah }\end{array}$ & 1872 \\
\hline 27 & Colorado State University & Larimer & Colorado & Weld & 1874 \\
\hline 28 & Mississippi State University & Oktibbeha & Mississippi & Clay; Lauderdale & 1878 \\
\hline 29 & South Dakota State University & Brookings & South Dakota & Minnehaha & 1881 \\
\hline 30 & North Dakota State University & Cass & North Dakota & Burleigh; Stutsman & 1883 \\
\hline 31 & University of Arizona & Pima & Arizona & Yuma; Pinal & 1885 \\
\hline 32 & University of Nevada & Washoe & Nevada & Carson City & 1885 \\
\hline 33 & North Carolina State University & Wake & North Carolina & Lenoir; Mecklenburg & 1886 \\
\hline 34 & University of Wyoming & Albany & Wyoming & Uinta; Laramie & 1886 \\
\hline 35 & Utah State University & Cache & Utah & Utah; Weber & 1888 \\
\hline 36 & Clemson University & Pickens & South Carolina & Richland & 1889 \\
\hline 37 & New Mexico State University & Dona Ana & New Mexico & San Miguel & 1889 \\
\hline 38 & University of Idaho & Latah & Idaho & Bonneville; Nez Perce & 1889 \\
\hline 39 & Oklahoma State University & Payne & Oklahoma & Oklahoma; Canadian & 1890 \\
\hline 40 & University of New Hampshire & Strafford & New Hampshire & Belknap; Grafton & 1891 \\
\hline 41 & Washington State University & Whitman & Washington & Yakima & 1891 \\
\hline 42 & Montana State University & Gallatin & Montana & Cascade & 1893 \\
\hline 43 & University of Connecticutt & Tolland & Connecticut & New Haven & 1893 \\
\hline 44 & University of Rhode Island & Washington & Rhode Island & Providence & 1894 \\
\hline 45 & University of California San Diego & San Diego & California & Los Angeles & 1905 \\
\hline 46 & University of Florida & Alachua & Florida & $\begin{array}{l}\text { Pinellas; Leon; Polk; Suwannee; Walton; Marion; } \\
\text { Osceola; Nassau; Duval; Columbia }\end{array}$ & 1905 \\
\hline 47 & University of California Davis & Yolo & California & $\begin{array}{l}\text { Stanislaus; Butte; San Joaquin; Monterey; } \\
\text { Contra Costa; Santa Cruz; Fresno; Merced; } \\
\text { Santa Clara; Solano; Sonoma; Glenn; Alameda }\end{array}$ & 1906 \\
\hline 48 & University of Hawaii & Honolulu & Hawaii & Maui; Hawaii & 1907 \\
\hline 49 & University of Alaska Fairbanks & Fairbanks North Star & Alaska & $\begin{array}{l}\text { Valdez-Cordova Census Area; Kenai Peninsula; } \\
\text { Kodiak Island; Sitka; Yukon-Koyukuk Census Area }\end{array}$ & 1917 \\
\hline 50 & University of California Irvine & Orange & California & Los Angeles & 1960 \\
\hline 51 & University of California Santa Cruz & Santa Cruz & California & Santa Clara & 1961 \\
\hline
\end{tabular}

Notes: List of land grant college experiments in the sample, along with the winning county and state, the runner-up counties, and the year in which the site selection decision took place. 
Table A4: Summary Statistics of Land Grant College Experiments, Including Low Quality Experiments

\begin{tabular}{lcccccc}
\hline & N & Mean & S.D. & Min & Median & Max \\
\hline \# Runner-Up Counties & 53 & 2.85 & 2.86 & 1.00 & 2.00 & 13.00 \\
Distance to College & 146 & 160.90 & 141.22 & 22.70 & 122.55 & $1,036.50$ \\
Year Established & 53 & 1880.08 & 22.24 & 1851.00 & 1872.00 & 1961.00
\end{tabular}

Notes: Number of runner-up counties, average distance from the runner-up counties to the college site, and experiment year for the land grant college experiments in the sample.

Table A5: Differences-in-Differences Results Comparing Land Grant College Counties to Runner-Up Counties, Including Low Quality Experiments

(a) Innovation and Population Outcomes

\begin{tabular}{lcccccc}
\hline \hline & $\log ($ Patents +1$)$ & $\log ($ Ag. Patents +1$)$ & Frac. Ag. Patents & New Wheat Variety & $\log ($ Total Pop. $)$ & $\log ($ Frac. Urban $)$ \\
\hline CollegeCounty * PostCollege & $0.527^{* *}$ & 0.0846 & -0.00460 & $0.0157^{* * *}$ & 0.0233 & 0.0288 \\
& $(0.183)$ & $(0.0683)$ & $(0.0114)$ & $(0.00432)$ & $(0.169)$ & $(0.0203)$ \\
& $0.205^{*}$ & $0.126^{* *}$ & 0.0120 & -0.00187 & $0.520^{* * *}$ & $0.0406^{* *}$ \\
PostCollege & $(0.0961)$ & $(0.0400)$ & $(0.00871)$ & $(0.00141)$ & $(0.0843)$ & $(0.0135)$ \\
& 33560 & 33560 & 24709 & 17178 & 31430 & 23903 \\
& 0.785 & 0.487 & 0.0527 & 0.00872 & 0.843 & 0.777 \\
\hline Num. Counties $\times$ Years & & & & & &
\end{tabular}

Standard errors in parentheses

${ }^{*} p<0.05,{ }^{* *} p<0.01,{ }^{* * *} p<0.001$

(b) Agricultural Outcomes

\begin{tabular}{lcccc}
\hline & $\log ($ Ag. Land Productivity) & $\log$ (Value Agricultural Output +1$)$ & $\log ($ Value Crops +1$)$ & $\log ($ Value Livestock Products +1$)$ \\
\hline CollegeCounty * PostCollege & -0.0330 & 0.0445 & 0.00622 & -0.161 \\
& $(0.100)$ & $(0.216)$ & $(0.268)$ & $(0.267)$ \\
PostCollege & 0.0962 & $0.467^{* * *}$ & $0.637^{* * *}$ & $0.730^{* * *}$ \\
& $(0.0547)$ & $(0.123)$ & $(0.190)$ & $(0.187)$ \\
\hline Num. Counties $\times$ Years & 27818 & 28808 & 28808 & 28808 \\
Adj. r-Sqr. & 0.906 & 0.903 & 0.947 & 0.933 \\
\hline \hline
\end{tabular}

Standard errors in parentheses

${ }^{*} p<0.05,{ }^{* *} p<0.01,{ }^{* * *} p<0.001$

Notes: Differences-in-differences regression results comparing land grant college counties to runner-up counties before and after establishing each college. Panel (a) uses innovation and population outcomes as the dependent variables. Panel (b) uses agricultural yield and output as the dependent variables. All regressions include county and year fixed effects. Standard errors are clustered at the county level. 
Table A6: Triple Differences Results Comparing the Land Grant to Non-Land Grant Colleges, Including Low Quality Experiments

(a) Innovation and Population Outcomes

\begin{tabular}{|c|c|c|c|c|c|c|}
\hline & $\log ($ Patents +1$)$ & $\log ($ Ag. Patents +1$)$ & Frac. Ag. Patents & New Wheat Variety & $\log$ (Total Pop.) & $\log$ (Frac. Urban) \\
\hline College $*$ Post-College $*$ Land Grant & $\begin{array}{c}-0.0648 \\
(0.267)\end{array}$ & $\begin{array}{c}-0.0149 \\
(0.102)\end{array}$ & $\begin{array}{c}0.000614 \\
(0.0152)\end{array}$ & $\begin{array}{c}0.0147^{* *} \\
(0.00452)\end{array}$ & $\begin{array}{l}-0.352 \\
(0.230)\end{array}$ & $\begin{array}{c}-0.0223 \\
(0.0273)\end{array}$ \\
\hline CollegeCounty * PostCollege & $\begin{array}{c}0.588^{* * *} \\
(0.144)\end{array}$ & $\begin{array}{c}0.0977^{*} \\
(0.0491)\end{array}$ & $\begin{array}{c}-0.00584 \\
(0.00827)\end{array}$ & $\begin{array}{c}0.00101 \\
(0.00129)\end{array}$ & $\begin{array}{l}0.380^{* *} \\
(0.118)\end{array}$ & $\begin{array}{l}0.0515^{* *} \\
(0.0166)\end{array}$ \\
\hline Post-College * Land Grant & $\begin{array}{l}0.264^{*} \\
(0.121)\end{array}$ & $\begin{array}{c}0.100^{*} \\
(0.0438)\end{array}$ & $\begin{array}{c}0.00810 \\
(0.00802)\end{array}$ & $\begin{array}{l}0.0000740 \\
(0.000952)\end{array}$ & $\begin{array}{l}0.329^{* *} \\
(0.102)\end{array}$ & $\begin{array}{c}0.0324^{*} \\
(0.0142)\end{array}$ \\
\hline PostCollege & $\begin{array}{l}-0.0469 \\
(0.0614)\end{array}$ & $\begin{array}{c}0.0144 \\
(0.0198)\end{array}$ & $\begin{array}{c}0.00430 \\
(0.00449)\end{array}$ & $\begin{array}{c}-0.000391 \\
(0.000710)\end{array}$ & $\begin{array}{c}0.0576 \\
(0.0517)\end{array}$ & $\begin{array}{c}0.00176 \\
(0.00819)\end{array}$ \\
\hline Num. Counties $\times$ Years & 121745 & 121745 & 82945 & 62076 & 113133 & 85563 \\
\hline Adj. r-Sqr. & 0.784 & 0.467 & 0.0537 & 0.00881 & 0.848 & 0.780 \\
\hline
\end{tabular}

Standard errors in parentheses

${ }^{*} p<0.05,{ }^{* *} p<0.01,{ }^{* * *} p<0.001$

(b) Agricultural Outcomes

\begin{tabular}{|c|c|c|c|c|}
\hline & $\log$ (Ag. Land Productivity) & $\log ($ Value Agricultural Output +1$)$ & $\log ($ Value Crops +1$)$ & $\log ($ Value Livestock Products +1$)$ \\
\hline College * Post-College * Land Grant & $\begin{array}{l}0.0229 \\
(0.127)\end{array}$ & $\begin{array}{c}0.379 \\
(0.275)\end{array}$ & $\begin{array}{c}0.337 \\
(0.348)\end{array}$ & $\begin{array}{c}0.205 \\
(0.324)\end{array}$ \\
\hline CollegeCounty $*$ PostCollege & $\begin{array}{l}-0.0564 \\
(0.0657)\end{array}$ & $\begin{array}{l}-0.338^{*} \\
(0.154)\end{array}$ & $\begin{array}{l}-0.333 \\
(0.186)\end{array}$ & $\begin{array}{l}-0.363^{*} \\
(0.172)\end{array}$ \\
\hline Post-College * Land Grant & $\begin{array}{l}0.00906 \\
(0.0527)\end{array}$ & $\begin{array}{l}-0.117 \\
(0.138)\end{array}$ & $\begin{array}{r}-0.0667 \\
(0.187)\end{array}$ & $\begin{array}{c}0.229 \\
(0.156)\end{array}$ \\
\hline PostCollege & $\begin{array}{l}0.117^{* * *} \\
(0.0272)\end{array}$ & $\begin{array}{l}0.468^{* * *} \\
(0.0812)\end{array}$ & $\begin{array}{l}0.413^{* * *} \\
(0.0912)\end{array}$ & $\begin{array}{l}0.364^{* * *} \\
(0.0923)\end{array}$ \\
\hline $\begin{array}{l}\text { Num. Counties } \times \text { Years } \\
\text { Adj. r-Sqr. }\end{array}$ & $\begin{array}{c}104525 \\
0.912\end{array}$ & $\begin{array}{c}108738 \\
0.872\end{array}$ & $\begin{array}{c}108738 \\
0.939\end{array}$ & $\begin{array}{c}108738 \\
0.922\end{array}$ \\
\hline
\end{tabular}

Standard errors in parentheses

${ }^{*} p<0.05,{ }^{* *} p<0.01,{ }^{* * *} p<0.001$

Notes: Triple differences regression results comparing college counties to runner-up counties before and after establishing each college for land grant and non-land grant colleges. Panel (a) uses innovation and population outcomes as the dependent variables. Panel (b) uses agricultural yield and output as the dependent variables. All regressions include county and year fixed effects. Standard errors are clustered at the county level. 
Table A7: Comparing Land Grant College Counties to Runner-Up Counties following Several Pieces of Legislation, Including Low Quality Experiments

(a) Innovation and Population Outcomes

\begin{tabular}{lccccc}
\hline \hline & $\log ($ Patents +1$)$ & $\log ($ Ag. Patents +1$)$ & Frac. Ag. Patents & $\log ($ Total Pop.) & $\log ($ Frac. Urban) \\
\hline College * Post-Morrill Act & 0.316 & 0.158 & $0.0624^{*}$ & -0.0796 & 0.0238 \\
& $(0.212)$ & $(0.122)$ & $(0.0295)$ & $(0.131)$ & $(0.0221)$ \\
College * Post-Hatch Act & $0.616^{*}$ & 0.113 & 0.0192 & 0.0160 & 0.0477 \\
& $(0.307)$ & $(0.125)$ & $(0.0188)$ & $(0.205)$ & $(0.0285)$ \\
College * Post-World War II & $0.788^{* * *}$ & 0.0894 & -0.00530 & $0.556^{* * *}$ & $0.0811^{*}$ \\
& $(0.196)$ & $(0.0654)$ & $(0.00706)$ & $(0.101)$ & $(0.0364)$ \\
\hline Num. Counties $\times$ Years & 10802 & 10802 & 8284 & 10629 & 8591 \\
Adj. r-Sqr. & 0.838 & 0.546 & 0.0678 & 0.898 & 0.835 \\
\hline \hline
\end{tabular}

Standard errors in parentheses

${ }^{*} p<0.05,{ }^{* *} p<0.01,{ }^{* * *} p<0.001$

(b) Agricultural Outcomes

\begin{tabular}{|c|c|c|c|c|}
\hline & $\log$ (Ag. Land Productivity) & $\log ($ Value Agricultural Output +1$)$ & $\log ($ Value Crops +1$)$ & $\log ($ Value Livestock Products +1$)$ \\
\hline College $*$ Post-Morrill Act & $\begin{array}{l}-0.0406 \\
(0.0526)\end{array}$ & $\begin{array}{c}0.00465 \\
(0.182)\end{array}$ & $\begin{array}{r}-0.0640 \\
(0.173)\end{array}$ & $\begin{array}{l}0.0674 \\
(0.223)\end{array}$ \\
\hline College * Post-Hatch Act & $\begin{array}{l}-0.0185 \\
(0.0844)\end{array}$ & $\begin{array}{l}0.0523 \\
(0.227)\end{array}$ & $\begin{array}{l}0.0172 \\
(0.240)\end{array}$ & $\begin{array}{l}-0.0567 \\
(0.232)\end{array}$ \\
\hline College * Post-World War II & $\begin{array}{c}0.101 \\
(0.0557)\end{array}$ & $\begin{array}{c}0.312 \\
(0.170)\end{array}$ & $\begin{array}{c}0.523 \\
(0.283)\end{array}$ & $\begin{array}{c}0.257 \\
(0.236)\end{array}$ \\
\hline $\begin{array}{l}\text { Num. Counties } \times \text { Years } \\
\text { Adj. r-Sqr. }\end{array}$ & $\begin{array}{l}9242 \\
0.943\end{array}$ & $\begin{array}{r}9692 \\
0.958\end{array}$ & $\begin{array}{l}9692 \\
0.974\end{array}$ & $\begin{array}{r}9692 \\
0.965\end{array}$ \\
\hline
\end{tabular}

Standard errors in parentheses

${ }^{*} p<0.05,{ }^{* *} p<0.01,{ }^{* * *} p<0.001$

Notes: Triple differences regression results comparing college counties to runner-up counties before and after several major land grant-related pieces of legislation for the cohort of land grant and non-land grant colleges established between 1860 and 1870. Panel (a) uses innovation and population outcomes as the dependent variables. Panel (b) uses agricultural yield and output as the dependent variables. All regressions include county and year fixed effects. Standard errors are clustered at the county level. 
Table A8: Comparing the Land Grant to Non-Land Grant Colleges following Several Pieces of Legislation, Including Low Quality Experiments

(a) Innovation and Population Outcomes

\begin{tabular}{lccccc}
\hline & $\log ($ Patents +1$)$ & $\log ($ Ag. Patents +1$)$ & Frac. Ag. Patents & $\log$ (Total Pop.) & $\log$ (Frac. Urban) \\
\hline College * Post-Morrill Act * Land Grant & 0.154 & 0.109 & 0.0329 & -0.121 & 0.0155 \\
& $(0.286)$ & $(0.152)$ & $(0.0419)$ & $(0.276)$ & $(0.0398)$ \\
College * Post-Hatch Act * Land Grant & 0.142 & 0.0725 & -0.00782 & -0.312 & -0.00278 \\
& $(0.468)$ & $(0.142)$ & $(0.0387)$ & $(0.299)$ & $(0.0581)$ \\
College * Post-World War II * Land Grant & 0.547 & 0.0215 & -0.00815 & 0.292 & 0.0208 \\
& $(0.302)$ & $(0.124)$ & $(0.0189)$ & $(0.194)$ & $(0.0575)$ \\
\hline Num. Counties $\times$ Years & 19637 & 19637 & 14552 & 19444 & 15659 \\
Adj. r-Sqr. & 0.813 & 0.482 & 0.0545 & 0.874 & 0.801 \\
\hline \hline
\end{tabular}

Standard errors in parentheses

${ }^{*} p<0.05,{ }^{* *} p<0.01,{ }^{* * *} p<0.001$

(b) Agricultural Outcomes

\begin{tabular}{|c|c|c|c|c|}
\hline & $\log$ (Ag. Land Productivity) & $\log ($ Value Agricultural Output +1$)$ & $\log ($ Value Crops +1$)$ & $\log ($ Value Livestock Products +1$)$ \\
\hline College * Post-Morrill Act * Land Grant & $\begin{array}{l}0.0172 \\
(0.105)\end{array}$ & $\begin{array}{c}0.136 \\
(0.335)\end{array}$ & $\begin{array}{c}0.101 \\
(0.308)\end{array}$ & $\begin{array}{c}0.225 \\
(0.405)\end{array}$ \\
\hline College * Post-Hatch Act * Land Grant & $\begin{array}{r}-0.0788 \\
(0.101)\end{array}$ & $\begin{array}{l}0.0163 \\
(0.352)\end{array}$ & $\begin{array}{l}0.0526 \\
(0.380)\end{array}$ & $\begin{array}{c}-0.0948 \\
(0.400)\end{array}$ \\
\hline College * Post-World War II * Land Grant & $\begin{array}{c}0.0468 \\
(0.0804)\end{array}$ & $\begin{array}{c}0.325 \\
(0.236)\end{array}$ & $\begin{array}{c}0.340 \\
(0.392)\end{array}$ & $\begin{array}{c}0.189 \\
(0.339)\end{array}$ \\
\hline $\begin{array}{l}\text { Num. Counties } \times \text { Years } \\
\text { Adj. r-Sqr. }\end{array}$ & $\begin{array}{l}17455 \\
0.948\end{array}$ & $\begin{array}{l}18235 \\
0.954\end{array}$ & $\begin{array}{l}18235 \\
0.971\end{array}$ & $\begin{array}{l}18235 \\
0.962\end{array}$ \\
\hline
\end{tabular}

Standard errors in parentheses

${ }^{*} p<0.05,{ }^{* *} p<0.01,{ }^{* * *} p<0.001$

Notes: Triple differences regression results comparing college counties to runner-up counties before and after several major land grant-related pieces of legislation for the cohort of land grant and non-land grant colleges established between 1860 and 1870. Panel (a) uses innovation and population outcomes as the dependent variables. Panel (b) uses agricultural yield and output as the dependent variables. All regressions include county and year fixed effects. Standard errors are clustered at the county level. 